\title{
norden
}

\section{TROUT 2013 - simulating VHS outbreaks}

Implementation of and activities related to a Viral Haemorrhagic Septicaemia (VHS)

simulation exercise for the Nordic and Baltic Countries conducted 4th -5th December 2013,

Bergen, Norway
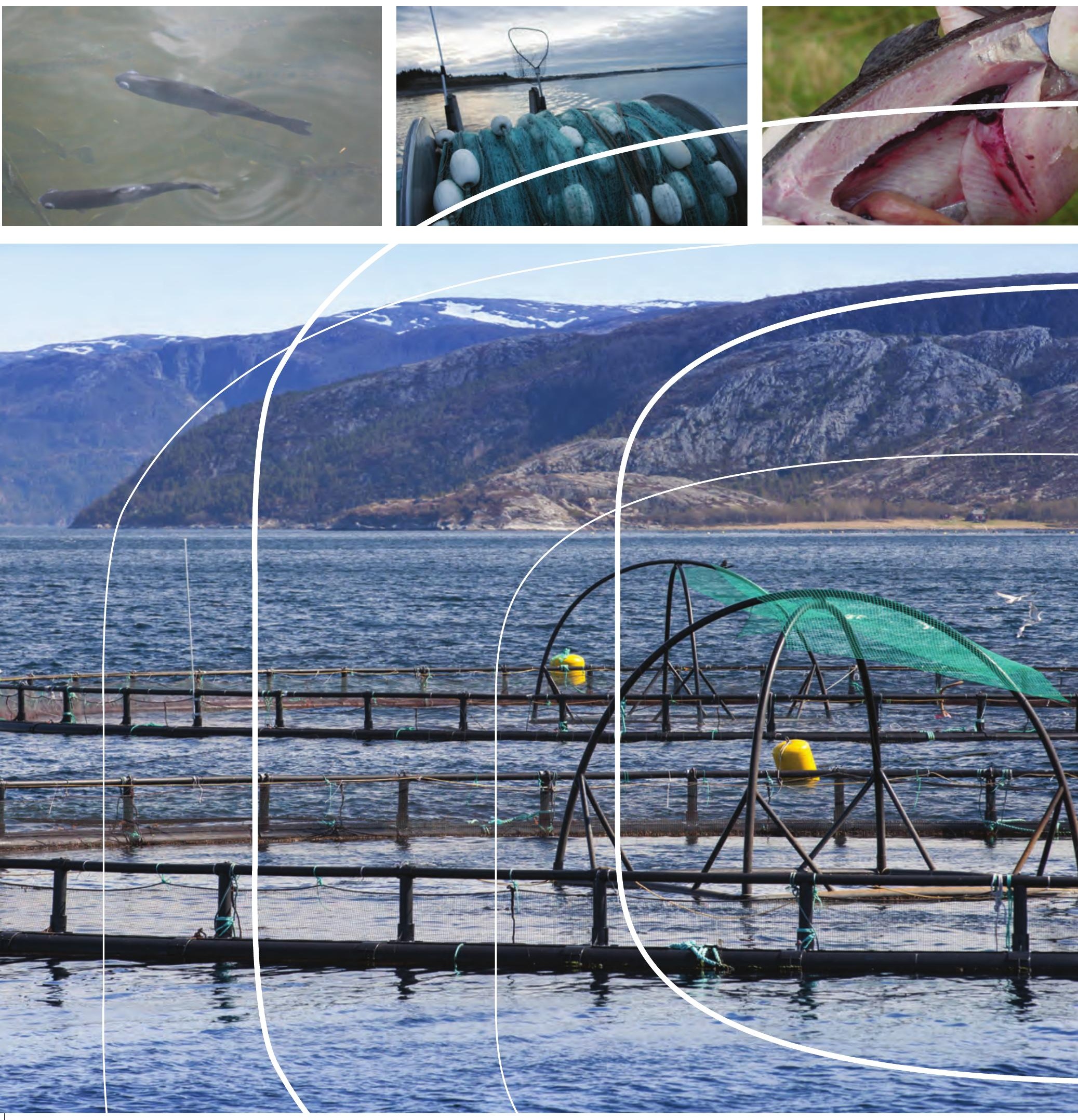

2 norden 



\section{TROUT 2013 - simulating VHS outbreaks}

Implementation of and activities related to a Viral Haemorrhagic Septicaemia (VHS) simulation exercise for the Nordic and Baltic Countries conducted 4th - 5th December 2013, Bergen, Norway

Siri Løtvedt and Jørgen M. Westergaard 
TROUT 2013 - simulating VHS outbreaks

Implementation of and activities related to a Viral Haemorrhagic Septicaemia (VHS)

simulation exercise for the Nordic and Baltic Countries conducted 4th - 5th December 2013,

Bergen, Norway

Siri Løtvedt and Jørgen M. Westergaard

ISBN 978-92-893-3905-6(PRINT)

ISBN 978-92-893-3906-3 (PDF)

ISBN 978-92-893-3907-0 (EPUB)

http://dx.doi.org/10.6027/TN2014-571

TemaNord 2014:571

ISSN 0908-6692

(C) Nordic Council of Ministers 2015

Layout: Hanne Lebech

Cover photo: Niels Jørgen Olesen/DTU; Signelements; ImageSelect

Print: Rosendahls-Schultz Grafisk

Printed in Denmark

This publication has been published with financial support by the Nordic Council of Ministers. However, the contents of this publication do not necessarily reflect the views, policies or recommendations of the Nordic Council of Ministers.

\section{www.norden.org/en/publications}

\section{Nordic co-operation}

Nordic co-operation is one of the world's most extensive forms of regional collaboration, involving Denmark, Finland, Iceland, Norway, Sweden, and the Faroe Islands, Greenland, and Åland.

Nordic co-operation has firm traditions in politics, the economy, and culture. It plays an important role in European and international collaboration, and aims at creating a strong Nordic community in a strong Europe.

Nordic co-operation seeks to safeguard Nordic and regional interests and principles in the global community. Common Nordic values help the region solidify its position as one of the world's most innovative and competitive.

\section{Nordic Council of Ministers}

Ved Stranden 18

DK-1061 Copenhagen K

Phone (+45) 33960200

www.norden.org 


\section{Content}

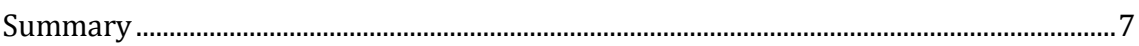

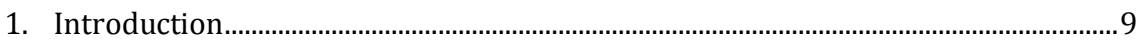

1.1 The preparatory work or the development of the exercise ............................ 10

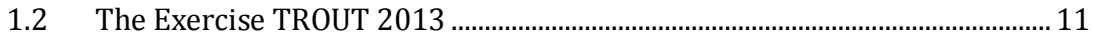

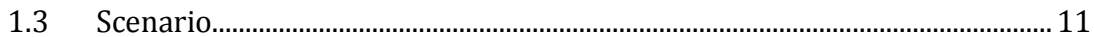

1.4 Working groups and group activities ............................................................. 12

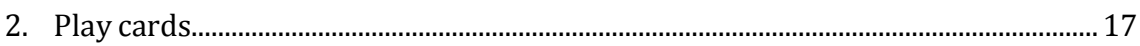

$2.1 \quad$ Play card part 1 .................................................................................................. 17

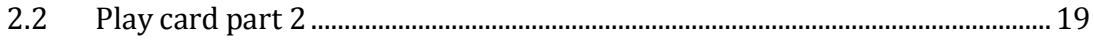

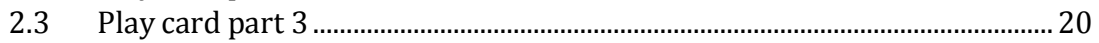

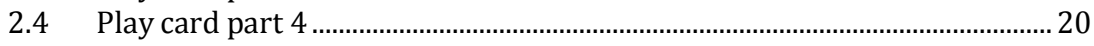

$2.5 \quad$ Play card part 5 …….................................................................................... 21

2.6 Additional information kept by directing staff ............................................... 21

2.7 Observations, conclusions and recommendations from the exercise ......... 24

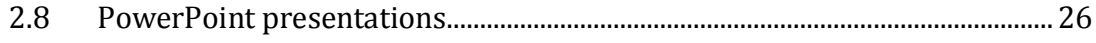

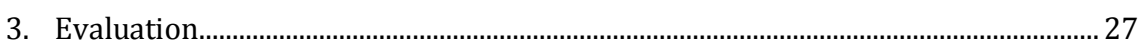

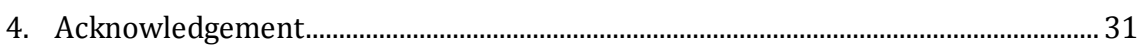

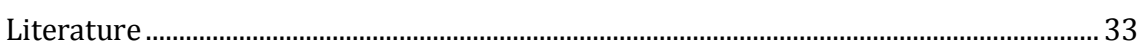

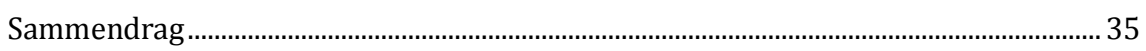

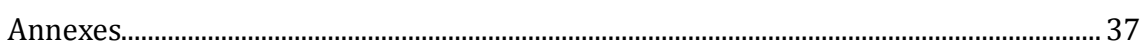

Annex 1. Programme ................................................................................................ 37

Annex 2. Organising Committee ............................................................................... 38

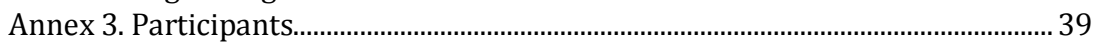

Annex 4. Information on rainbow trout farming and VHS in participating

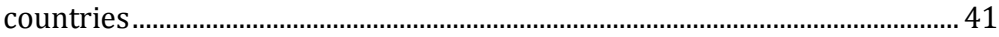

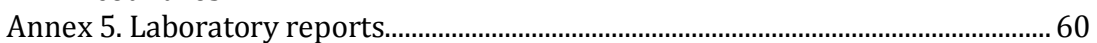

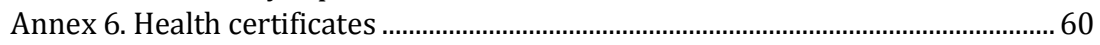

Annex 7. Biomass information ...................................................................................... 61 



\section{Summary}

This report contains details of a Nordic-Baltic Viral Haemorrhagic Septicaemia (VHS) table - top simulation exercise, codenamed TROUT 2013. The scenario for the exercise was prepared by the Norwegian Food Safety Authority and the implementation took place in Bergen. During the overall planning and preparatory work the Nordic-Baltic Veterinary Contingency Group took into account that many marine aquaculture industries and pond fish systems located in the Nordic-Baltic countries in the past have suffered major production losses due to fish disease epidemics. One of the most devastating viral diseases is: Viral haemorrhagic septicaemia (VHS).

The aim of the exercise was to test National VHS Contingency Plans. The exercise, based on realistic but simulated suspicions and outbreaks in existing farms and facilities in Norway, was very well prepared by fish experts in Norway.

The participants - all from veterinary administration and diagnostic laboratories -were during the exercise allocated to different working groups with the objective to discuss challenges related to disease surveillance, prevention and eradication. The focus was on training and the familiarization with the provisions and measures given in Council Directive 2006/88/EC and National Contingency Plans. The participants came from 9 countries - Denmark, Estonia, Faroe Islands, Finland, Åland, Iceland, Latvia, Lithuania, Norway and Sweden.

The conduct of the exercise TROUT 2013 was found to be a very valuable tool for testing National VHS contingency plans and the exercise was a success. The short training session carried out just prior to the exercise gave the participants an opportunity to be updated on the virology, diagnostic methods, epidemiology and distribution of VHS and on the surveillance and control measures outlined in the EU legislation and OIE Aquatic Animal Health Code. The different elements of the TROUT 2013 carried out during the exercise assisted the participants in obtaining a better understanding of contingency planning and the changing disease situation during the exercise exposed the participants to risk assessments and decision making which may occur during real VHS outbreaks. 



\section{Introduction}

Viral hemorrhagic septicemia (VHS) - also known as "Egtved disease" - is a viral disease with a large number of susceptible species. The disease may be regarded as a model disease for several infectious diseases that may be a threat to farmed or wild fish stocks in the Nordic and Baltic countries.

Aim

Testing of National Contingency Plans.

\section{Goals - objectives}

To explore to what extent the provisions of Council Directive 2006/88/EC on Fish health are being taken into account and applied in a case of outbreak of VHS. In particular with regard to:

- The availability of national plans available to handle an outbreak.

- Trained personnel and laboratory capacity.

- The approval or registration of aquaculture facilities, processing plants and animal by product plants.

- Transport to processing plants and methods applied during processing in order to avoid spreading of infectious diseases such as VHS.

- Regulations on placing suspected infected or confirmed infected fish on the marked.

- International information in a case of an outbreak.

- Handling of infected dead fish.

- The application of animal welfare legislation during a large outbreak.

\section{Type of exercise}

"Trout 2013" was organized as a "Table-Top-Exercise". The participants, allocated to different working groups, were invited to perform activities in specified rooms and not supposed to take make contact to institutions or persons outside the rooms with the exception that questions related to the exercise should be submitted to the organizer/directing staff( Dr. Aud Skrudland). The directing staff was placed in a separate room in the building where the exercise took place. The work performed as directing staff included to play the owners of the fish farms affected by disease. 


\section{Participants}

Each of the Nordic and Baltic countries was invited to send three participants to the exercise. At least one of the participants from each country should represent the competent authority and one should represent an official laboratory. Many of the participants had firsthand experience in the diagnosis and treatment of fish diseases, while others were less experienced.

The participants, a total of 28 , were during the exercise divided in 4 groups.

A mediator for each group was designated by the directing staff while the members of the group appointed a reporter/ speaker for the group.

The participants discussed in the working groups the preparation and dispatch of letters, notifications etc and the nature of the content, but they were not requested to draft and dispatch documents.

During discussions and decision making all legal references should refer to the legislation in force (common directives).

Within the context of the objectives of the exercise and the framework of Council Directive 2006/88/EC it was anticipated that the participants during discussions on risk evaluations, proposals on disease surveillance, prevention and eradication would learn from each other.

The results from the discussions and decisions made by the different groups were presented during plenary sessions. Equipment and facilities were made available for preparation of and delivery of Power-point presentations.

It was highlighted at the outset of the exercise that there would not be one specific solution to the problems met during the exercise - the situation in the different countries and the political "guide-lines" differ.

\section{Observers}

The Nordic-Baltic Veterinary Contingency Group (N-B VCG) members and one of the participants from the Norwegian Veterinary Institute acted as observers during the exercise.

\subsection{The preparatory work or the development of the exercise}

The planning of the exercise TROUT 2013 started in March 2013. A working group of 3 persons from the Norwegian Food Safety Authority was appointed to carry out the preparatory work. The Norwegian member of the Nordic-Baltic Veterinary Contingency Group (N-B VCG) led the 
group and two fish experts provided expert knowledge on fish diseases and on handling control measures when disease outbreaks occur in the aquaculture industry. The working group did during the preparatory work consult the Norwegian Veterinary Institute on certain issues; it had five meetings of which four were video meetings. The duration of the preparatory work was about 150 hours.

\subsection{The Exercise TROUT 2013}

Many marine aquaculture industries and pond fish systems located in the Nordic-Baltic countries have suffered major production losses due to fish disease epidemics. Some of the most devastating viral diseases are: Infectious salmon anaemia (ISA), Infectious pancreatic necrosis (IPN) and Viral haemorrhagic septicaemia (VHS).

The Exercise TROUT 2013 was planned and designed as a table-top exercise; an exercise which simulated a VHS emergency situation in an informal, stress-free environment. The participants - all from veterinary administration and diagnostic laboratories -were allocated to different working groups with the objective to discuss problems related to disease surveillance, prevention and eradication. The focus was on training and the familiarization with the provisions and measures given in Council Directive 2006/88/EC.

Viral haemorrhagic septicaemia was selected for the emergency situation as VHS in recent years have caused outbreaks

VHS occurs in an acute to chronic form of trout's. The clinical appearance of the disease varies considerable. The most notable lesion is widespread haemorrhages in the liver, adipose tissue, and within skeletal muscle. Chronically infected farmed and wild trout are the most common source of infection. Other wild fish species may act as reservoir of the virus.

No vaccine is commercially available.

\subsection{Scenario}

In November 2013, the competent authority at the local level received a telephone call from a fish farmer who reported elevated mortality in rainbow trout kept in several of the farm ponds.

A veterinarian visited the farm and suspected VHS due to the behavior of the fish and on post mortem findings. Some fish showed strange 
swimming behavior and the post morten findings included ophthalmus in some fish, pale gills and petechial hemorrhages in internal organs and in the muscles in others. Samples from 5 affected fish were sent to the laboratory for histological, virological and bacteriological examinations.

The affected farm was located in an area defined as a VHS disease free zone.

During the epidemiological investigation it was revealed that the farm had sold harvested, ungutted fish to another farm 3 weeks prior to the disease outbreak. It was furthermore learned that the only intake of biological material during the last 3 months had been eyed eggs bought in Denmark. However, there were also other possible sources of infection in the surroundings.

The samples submitted to the laboratory were 4 days later by the National Reference Laboratory found positive for VHS by PCR testing and by histology.

\subsection{Working groups and group activities}

The opening session of the simulation exercise commenced with a presentation by Professor Niels Jørgen Olesen, Denmark about the clinic, virus and distribution of VHS and a presentation by Dr. Aud Skrudland, Norway. Dr. Aud Skrudland highlighted the EU legislation on fish disease surveillance, control measures, placing of fish on the market and animal welfare and furthermore the relevant OIE guidelines.

For the group work during the exercise the participants were divided into 4 groups and each group had about 7 participants. The composition of the different groups took into the working experiences of the individual participants and their position in national veterinary administrations or diagnostic laboratories. Furthermore, the nationalities of participants were considered in order to have different nationalities represented in the 4 groups. The competent authorities and National Reference Laboratories were represented in each group.

The organizers of the exercise appointed one mediator for each group and the members of each group selected a speaker for the group.

The groups were placed in separate rooms and were gathered for plenary sessions at regular intervals for discussion and for being updated on details related to the outbreak. During and after each plenary session the groups received new "playing cards".

A main aim of the group work was that the participants were given an opportunity to learn from each other. Risk assessments and practical 
solutions were discussed. It was not anticipated that the groups should prepare specific letters, notifications, regulations etc, but the members of the groups were expected to discuss who should receive information, letters etc and the nature of the content. When references were made to legislation it was agreed to refer to the EU directives applicable in all countries as there could be minor differences in the national regulations.

The summary of group discussions were presented to and discussed by the participants of the 4 groups after each session.

There was no specific solution to the challenges faced during the exercise - the objectives with regard to disease control were considered by the participants to be the same in the countries, but the approach outlined in National Contingency Plans could differ.

The composition of the 4 working groups is given below.

\section{Group 1}

- Anders Hellstrøm, Sweden, Laboratory (Lab).

- Johan Teige, Norway, Competent Authority (CA).

- Pia Vennerstrøm, Finland, CA.

- Sigridur Gisladottir, Iceland, Lab.

- Hele-Mai Sammel, Estonia, CA.

- Orinta Rimasaite, Lithuania, Lab.

- Torben Grubbe, Denmark, CA.

\section{Group 2}

- Niels Jørgen Olsen, Denmark, Lab.

- Veronica Colmander, Sweden, CA.

- Tuija Gadd, Finland, CA.

- Triin Tedersoo, Estonia, Lab.

- Mantas Staskevicius, Lithuania, CA.

- Ingibjørg Egholm, Faroe Islands, CA.

- Martin Serzant, Latvia, CA.

\section{Group 3}

- Martin Binde, Norway, CA.

- Sigridur Gudmundsdottir, Iceland, Lab.

- Charlotte Axen, Sweden, Lab.

- Jacob Nordstrøm-Riddarborg, Åland, CA.

- Madara Stinka, Latvia, CA.

- Marius Masiulis, Lithuania, CA.

- Birna Mørkøre, Faroe Islands, CA. 


\section{Group 4}

- Britt Hjeltnes, Norway, Lab.

- Shabnam Beikmohammadi, Sweden, CA.

- Henrik Korsholm Larsen, Denmark, CA.

- Audur Arnthorsdottir, Iceland, CA.

- Olga Piirik, Estonia, CA.

- Ieva Rodze, Latvia, Lab.

- Debes H. Christiansen, Faroe Islands, Lab.

\subsubsection{Master File for the simulation exercise}

\section{Wednesday December $4^{\text {th }} 2013$}

- 12.30-15.30: Exercise part 1 Aud Skrudland and Ivar Hellesnes, Norway.

\begin{tabular}{llc}
\hline Telephone call from fish farmer to one participant. & Play, Ivar & 12.30 \\
$\begin{array}{l}\text { Playcard part 1 } \\
\text { Map case } \\
\text { Lay-out farm A }\end{array}$ & Presentation Aud & 12.40 \\
$\begin{array}{l}\text { Playcard part 2 } \\
\text { Lab-report 1a } \\
\text { Lay-out farm B. }\end{array}$ & Delivered to groups, Siri & 13.30 \\
$\begin{array}{l}\text { Playcard part 3 } \\
\text { Lab-report 1b }\end{array}$ & \\
\hline
\end{tabular}

- 15.30-17.00: Presentations from the groups and discussion, Siri Løtvedt

- 17.15-17.45:Meeting for staff

\section{Thursday December $5^{\text {th }}$}

- 08.30-08.45: Motivation for the day, Siri Løtvedt and Aud Skrudland.

- 08.45-12.00: Exercise part 2: Group discussions of scenario, Aud and Ivar.

\begin{tabular}{llc}
\hline $\begin{array}{l}\text { Playcard part } 4 \\
\text { Lab-report 2a }\end{array}$ & Presentation, Aud & $08: 45$ \\
$\begin{array}{l}\text { Playcard part } 5 \\
\text { Lab-report 2b, } 3 \text { and } 4 \text { /wildfish). }\end{array}$ & Delivered at groups, Siri & 10.30 \\
\hline
\end{tabular}

- 12.00-13.00: Lunch.

- 13.00-14.15: Presentation and discussion, Siri.

- 14.15-14.30: Pause. 
- 14.30-15.00: Presentation and discussion, Siri.

- 15.00-16.00: Evaluation of the exercise, Siri Løtvedt and Jørgen Westergaard.

1. Discussions in groups on the value of this exercise.

2. Provide information on 3 positive experiences and 3 points on how to make it better.

3. Evaluation form to be completed by participants. 



\section{Play cards}

\subsection{Play card part 1}

It is in November and the Competent Authority in your country at local level has got a telephone from a fish farm who reports elevated mortality on rainbow trout in several of their ponds. FARM A

The Veterinarian has been on the farm today and she says that she suspects VHS due to findings on post mortem and behavior of fish. Some affected fish shows strange swimming behavior. Post mortem performed on affected or dead fish shows ophthalmus on some fish, pale gills and petechial hemorrhages in internal organs and in muscle in others. Samples of 5 affected fish have been sent in to lab, material for histology, virus growth and bacteriology.

Farms in the area are in a defined as VHS disease free zone.

- What are the criteria for suspicion and confirmed diagnose, and for verification of diagnosis?

- Discuss what actions should be taken by Competent Authority at this point. 


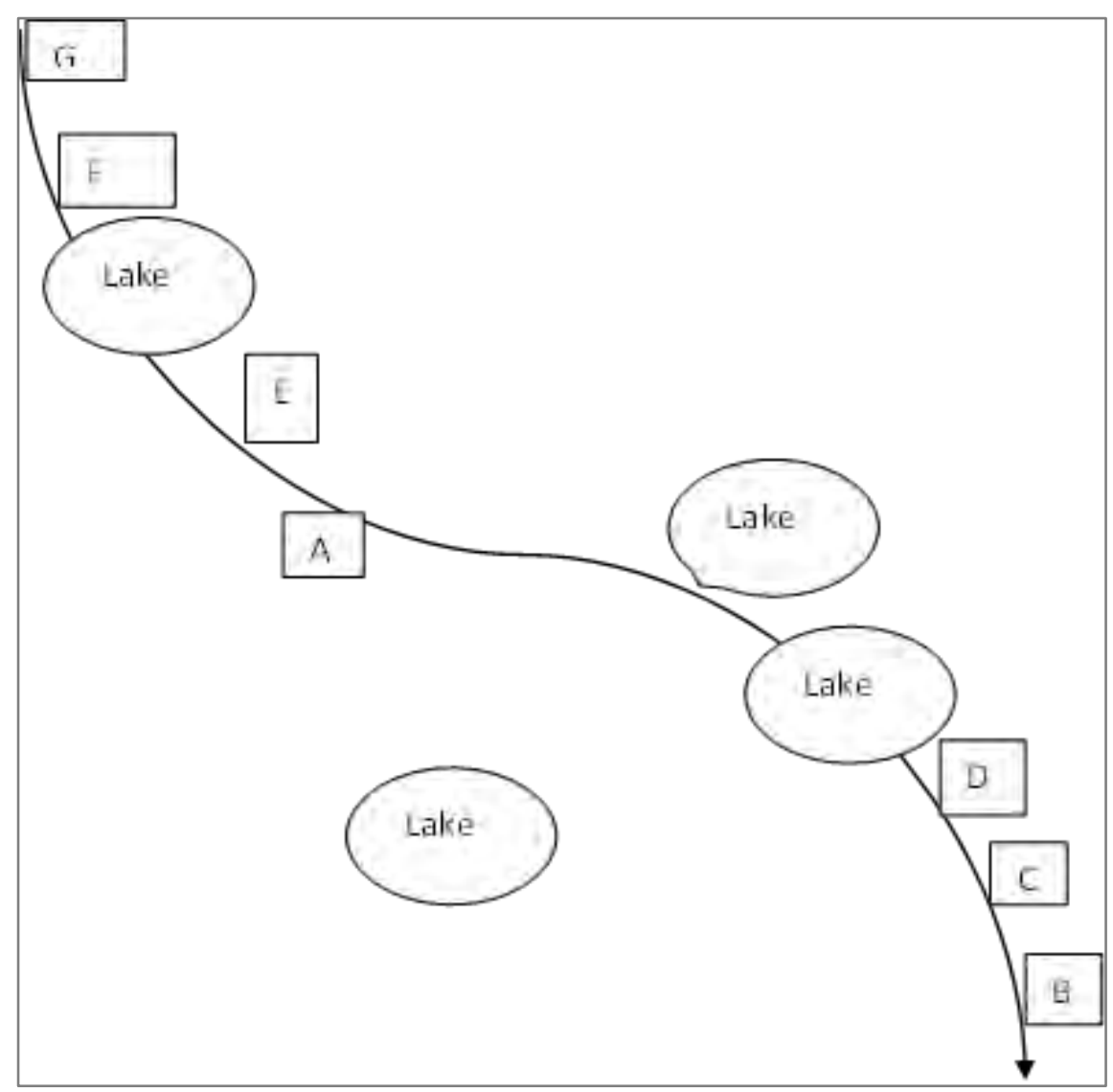

Map of area with the authorized fish farms A, B, C, D, E, F and G.

The tentative information available with regard to farms C, D, F and G shown on the map are:

- 50,000 rainbow-trout each. Average $0.6 \mathrm{~kg}$

- outdoor ponds

- water supply from ground (subsoil water)

- water outlet to lake

- no elevated mortality.

The situation with regard to Farm $\mathrm{E}$ is the following:

- Small trial farm with floating cages in lake.

- Arctic Char.

- 6,000 a $0.5 \mathrm{~kg}$. 
Migration of fish upstreams from lake to ponds not possible

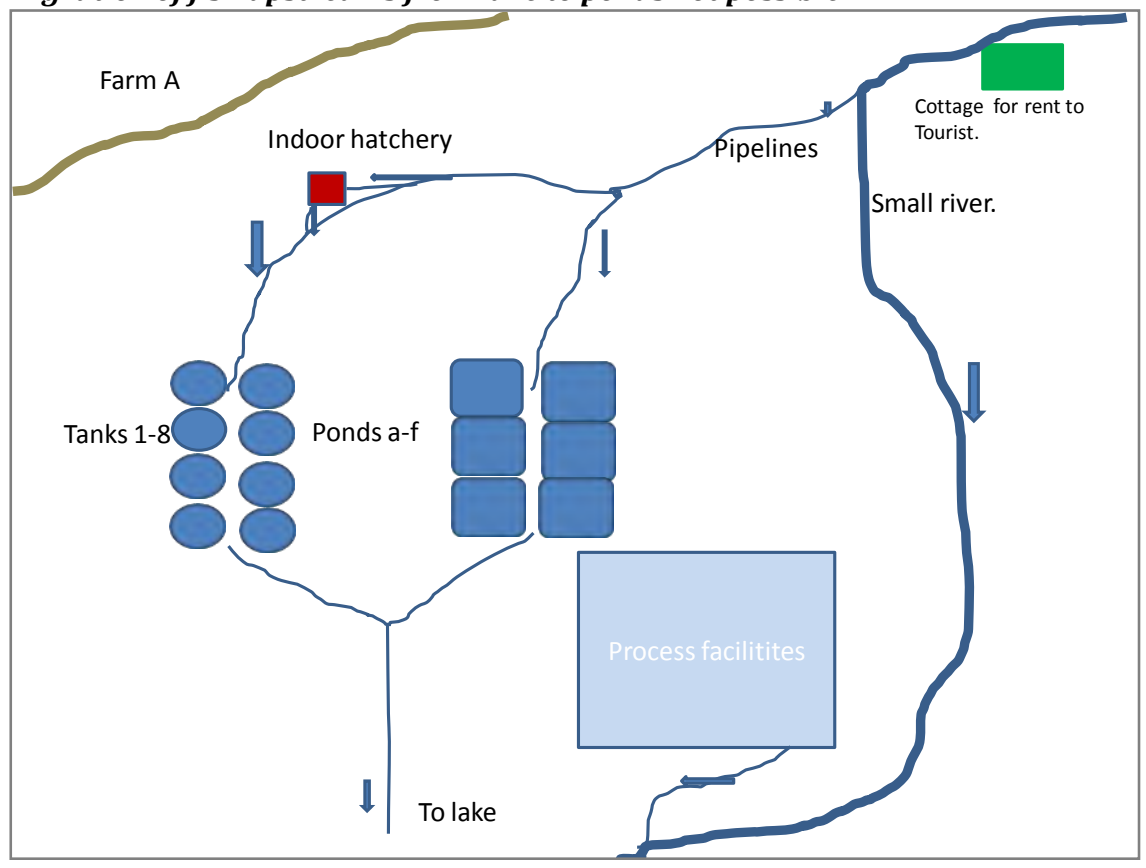

\subsection{Play card part 2}

The inspector gets information that farm A has sold harvested, unguttet fish to farm B 2 weeks ago. Farm B needed more supplies to finish a production of smoked trout in their facilities close to the fish ponds.

Discuss what actions should be taken by Competent Authority at this point.

Preliminary lab reports are sent over to Competent Authority from the local veterinarian.

See lab report from 20th November 2013 (Annex 5). 


\section{Lay out farm B}

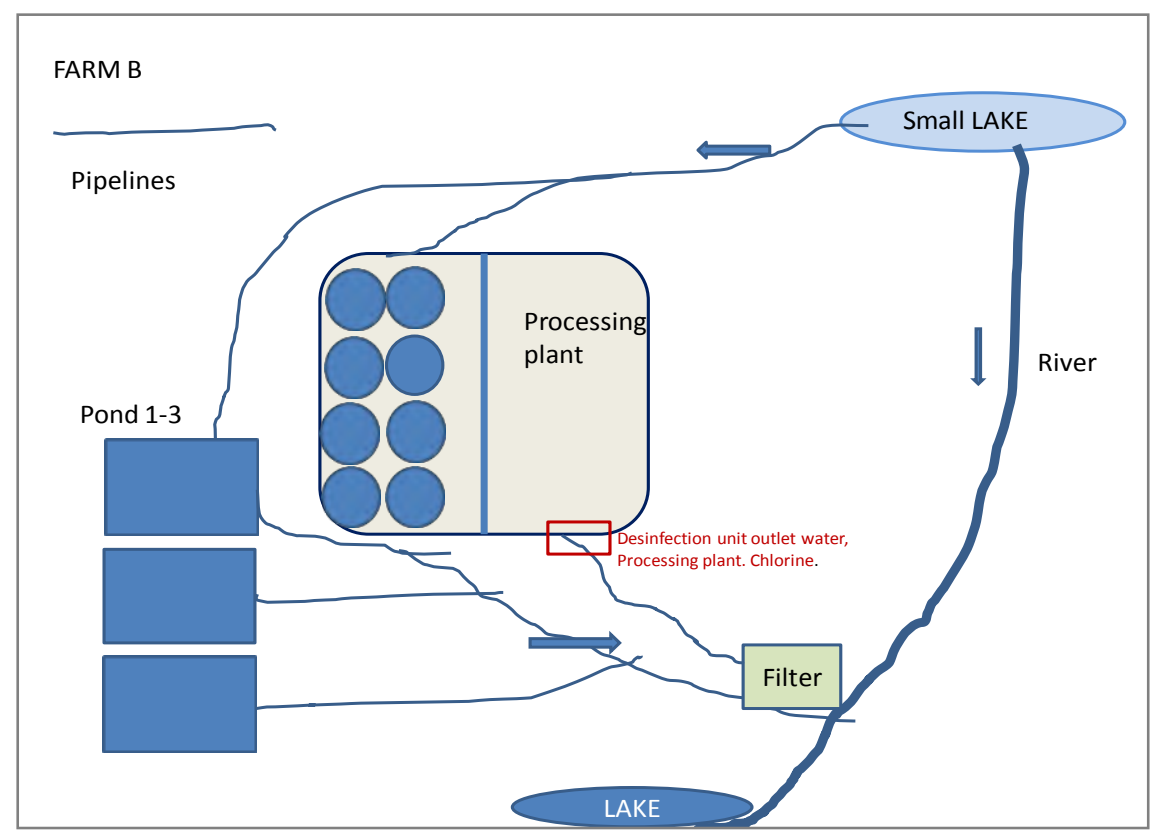

\subsection{Play card part 3}

Answer from lab has arrived and are send over to Competent Authority from the local veterinarian.

The inspector also gets information that the only intake of biological material the last 3 months have been eyed eggs bought from Denmark.

See lab report from 22th November 2013(Annex 5).

\subsection{Play card part 4}

4 days later: Samples have been analyses on the national reference laboratory. The samples were found positive for VHS on PCR and histology. Answers from virus growth not yet ready.

The mortality in farm A is still elevated, but does not seem to continue to rise.

Discuss what actions should be taken to eradicate the disease from the farm and area. This includes the necessary notifications, distribution of information, legal requirements, surveillance and activities for regaining VHS free status.

See Lab report from 25th November 2013 (Annex 5). 


\subsection{Play card part 5}

How would you regard the situation if wild Artic char (Salvelinus alpinus) from the lake were diagnosed with VHS, 2 months later?

See lab report 26th November 2013, 20th December 2013 and 29th January 2014(Annex 5).

How would you be able to harvest/stamp out fish from several farms in a short period of time. What would be the most challenging issues from your point of view? Considerations should be given to fish health, fish welfare and/or animal by-products.

\subsection{Additional information kept by directing staff}

Information to be given to working groups on request from the groups

- Biomass, mortality and temperature, farm A.

- Biomass, mortality and temperature, farm B.

- Basic information on farms C-E.

- Certificate for eggs from Denmark.

\subsubsection{Expected issues day 1}

- Criteria for suspicion OIE manual 7.1.

- Differential diagnosis.

- National contingency plan (2006/88/EC art 47).

- Farms in the area, (2006/88/EC, art 6).

- Recent controls and sampling by CA (2006/88/EC art 7).

- Notification (2006/88/EC art 26, 27):

- Internally.

- National.

- International.

- Immediate actions to prevent spread of VHS (2006/88/EC art 28).

- "Freeze"situation. How is this done?

- Movement of fish, personnel, dead fish, processed fish, vehicles and equipment.

- Epizootic investigation survey situation (2006/88/EC art 29):

- Name and address. License, site etc.

- Other farms in the area that could be affected. 
- Biomass, number of fish, age and size. (2006/88/EC art 8).

- Mortality data (2006/88 art 8).

- Fish supplied to farm, fish out from the farm (2006/88/EC, art 8).

○ Wild fish?

- Inspection and sampling (OIE).

- Number of fish.

- What kind of samples.

○ Analyses.

- Necessary equipment and personnel.

- Capacity laboratory.

- Unregistered farms (2006/88/EC. Chapter II).

- Any treatment with withdrawal time that may influence harvesting?

\subsubsection{Expected issues day 2}

\section{6/88/EC Section 4}

- Verification of diagnosis (art 57) (OIE 7.2).

- Notification (art 53).

- Information.

- Control zone. Eradication area and surveillance area (art 39).

- Epidemiological survey (art 29).

- Decisions on eradication (Art 34, 35, 36).

- Which fish can be harvested at what time, which fish has to be destructed? (art 33).

- Restrictions on harvested fish (art 33).

- Cleaning and disinfection of premises (art 35).

- Fallowing time (art 35).

- Compensation to farmers affected.

\section{Wild fish}

Implementation of Council Directive 2006/88/EC article 40

\section{Several farms affected}

- Animal welfare.

- Capacity by-products handling. 
Possible Questions and Answers to be used during the exercise

\begin{tabular}{|c|c|c|}
\hline & & $\begin{array}{r}\text { Asked for by } \\
\text { group }\end{array}$ \\
\hline Biomass & Data for farm A & $3,2,4,1$ \\
\hline Biomass & Data for farm B & $3,2,4,1$ \\
\hline \multicolumn{3}{|l|}{ Farm C-E } \\
\hline How is dead fish handled? & $\begin{array}{l}\text { Each farm has a } 1 \mathrm{~m}^{3} \text { container with a grinder. Dead } \\
\text { fish is collected, grinded and added formic acid to } \\
\mathrm{pH} \text { lower than } 4 \text {. } \\
\text { Monthly pick-up by category } 2 \text { plant. }\end{array}$ & 2,4 \\
\hline Farm C.D.F.G & $\begin{array}{l}50,000 \text { rainbow-trout each. Average } 0.6 \mathrm{~kg} \text {. } \\
\text { Water supply from ground (subsoil water). } \\
\text { Water outlet to lake. } \\
\text { No elevated mortality. }\end{array}$ & 4 \\
\hline Farm E & $\begin{array}{l}\text { Small trial farm with floating cages in lake. } \\
\text { Artic Char (Salvelinus alpinus). } \\
6,000 \text { a } 0.5 \mathrm{~kg} \text {. }\end{array}$ & 4 \\
\hline $\begin{array}{l}\text { Where in Denmark did the } \\
\text { eyed eggs come from? }\end{array}$ & $\begin{array}{l}\text { Farmer bought these from Salmobreed, a local } \\
\text { breeding company, and do not know the name of } \\
\text { the farm in Denmark. }\end{array}$ & 4 \\
\hline $\begin{array}{l}\text { Certificate on eggs from } \\
\text { Denmark }\end{array}$ & Copied to be delivered out if asked for. & $4,1,3$ \\
\hline $\begin{array}{l}\text { Egg from Denmark supplied to } \\
\text { other farms }\end{array}$ & One in the same country but a very different area. & 4 \\
\hline Cottage for rent at farm A. & $\begin{array}{l}\text { Used mainly by Norwegians in the winter. For skiing } \\
\text { purposes. } \\
\text { This autumn rented out to a group of workers from } \\
\text { Aaland Islands in Finland. They work on agriculture } \\
\text { farms. Brought fish from home for smoking. }\end{array}$ & $2,3,1$ \\
\hline Fish Health problems & $\begin{array}{l}\text { Regular outbreaks of enteric redmouth disease } \\
\text { (ERM) }\end{array}$ & \\
\hline Any treatment the last month. & $\begin{array}{l}\text { A case of Yersinia on fry }<5 \text { gram } 3 \text { weeks ago were } \\
\text { treated with Flumequin. Withdrawaltime } 40 \text { days. }\end{array}$ & 2 \\
\hline Vaccination & $\begin{array}{l}\text { Fry are dip vaccinated against enteric redmouth } \\
\text { disease }\end{array}$ & \\
\hline $\begin{array}{l}\text { Wild fish upstream from lake } \\
\text { to river at farm } A \text { ? }\end{array}$ & Could not be excluded & \\
\hline $\begin{array}{l}\text { Wild fish upstream from lake } \\
\text { to other farms }\end{array}$ & Not possible & \\
\hline Feed used in all farms & Commercial dry feed from Biomar. & 2,1 \\
\hline Biosecurity in farm & $\begin{array}{l}\text { Open air tanks, must be regarded as one epidemio- } \\
\text { logical unit. Two men employed that do all the work } \\
\text { included harvesting No treatment of effluent water } \\
\text { from farm or process plant. }\end{array}$ & 4,2 \\
\hline
\end{tabular}




\begin{tabular}{|c|c|c|}
\hline & & $\begin{array}{r}\text { Asked for by } \\
\text { group }\end{array}$ \\
\hline Marked size & $\begin{array}{l}\text { Fish over } 1 \mathrm{~kg} \text { may be harvested and sold for human } \\
\text { consumption }\end{array}$ & 4 \\
\hline Farm B and other farms & National eggs from VHS free territories. & 4 \\
\hline Slaughter fish from A to B. & In disposable boxes on ice. & 1 \\
\hline Capasity slaughtering farm A & $\begin{array}{l}3-4,000 \text { fish a day. } \\
\text { The limiting factors are trained personell and } \\
\text { capacity at bleeding tank. }\end{array}$ & 4 \\
\hline Farms downstream from lake & None goes directly to the ocean. & 1 \\
\hline Wild fish in lake & Brown trout (Salmo trutta) and artic char & \\
\hline Test in other farms & $\begin{array}{l}150 \text { fish tested in all the other farms. All negative for } \\
\text { VHS }\end{array}$ & \\
\hline
\end{tabular}

\subsection{Observations, conclusions and recommendations from the exercise}

The simulation exercise TROUT 2013 was a table-top exercise and the primary purpose of the exercise was to test National VHS Contingency Plans. The exercise was based on realistic but simulated suspicions and outbreaks in existing farms and facilities in Norway. The Nordic -Baltic Veterinary Contingency Group was responsible for the initiative of the exercise and for defining the objectives, while the organizing committee was responsible for the preparation and implementation of the exercise. The TROUT 2013 exercise had Participants of from 9 countries - Denmark, Estonia, Faroe Islands, Finland, Åland, Iceland, Latvia, Lithuania, Norway and Sweden -and it was operated under the provisions of EU legislation and in particular with regard to Council Directive 2006/88/EC 2006 on animal health requirements for aquaculture animals and products thereof, and on the prevention and control of certain diseases in aquatic animals.

On the whole, the exercise TROUT 2013 can be considered as being a very valuable tool for testing VHS contingency plans and a success. The training session carried out just prior to the exercise gave the participants an opportunity to be updated on the virology, diagnostic methods, epidemiology and distribution of VHS and on the surveillance and control measures outlined in the EU legislation and OIE Aquatic Animal Health Code. The different elements of the TROUT 2013 carried out on the $4^{\text {th }}$ and $5^{\text {th }}$ December assisted the participants in obtaining a better understanding of contingency planning and the changing disease situa- 
tion during the exercise exposed the participants to risk assessments and decision making which may occur during real VHS outbreaks.

The observations given below elucidate the success of the exercise and can be considered as good achievements:

- The cooperation between the Nordic-Baltic countries with regard to a joint effort for testing Contingency plans and the preparation and implementation of a two-day exercise involving scientists and official veterinarians from 9 countries is a rare achievement.

- The exercise was developed around clear defined objectives and well constructed with realistic situations occurring in fish farming.

- The members of the 4 working groups, who were representing National diagnostic laboratories and officials in veterinary administrations responsible for fish disease surveillance and control, were all heavily engaged in the discussions on problem solving and decision making.

- The directing staff of the exercise provided an excellent support during the implementation of the exercise and ensured that all working groups remained on track.

- It was appreciated by many participants that there were no preconceived opinions and answers to the challenges faced during the exercise.

A few points were noted where improvements should be considered for future exercises. These include:

- Documents to the participants should be distributed well in advance.

- The rooms made available for the working groups should be well equipped with computers, projectors and internet access.

- The role of the directing staff and of leaders of the working groups should be well defined and known by the participants.

\section{Recommendations}

The use of a simulation exercise is considered as being a very important tool for testing contingency plans. It is recommended that a Nordic-Baltic simulation exercise should be conducted every third year with preparations carried out in each of the participating countries. 


\subsection{PowerPoint presentations}

The two PowerPoint presentations given at the start of the programme provided valuable information for the conduct of the simulation exercise and were entitled respectively:

1. Viral Haemorrhagic Septicemia (VHS): clinic, virus and distribution.

2. Regulations.

The link to the presentations is given below:

1. Link to "Viral Haemorrhagic Septicemia (VHS): clinic, virus and distribution":

http://norden.diva-portal.org/smash/get/diva2:794617/

ATTACHMENT01.pdf

2. Link "Regulations":

http://norden.diva-portal.org/smash/get/diva2:794617/

ATTACHMENT02.pdf 


\section{Evaluation}

An evaluation form was as a part of the hand outs given to all participants before the start of the exercise.The form consisted of 2 parts:

- General questions.

- Complementary comments.

The evaluation scale to be used for the general questions was: $1=$ poor and $5=$ excellent. A total of 28 completed evaluation forms were collected at the end of the exercise and the information - feedback - obtained from the forms is given in the table below:

\begin{tabular}{|c|c|c|c|c|c|}
\hline General questions & 1 & 2 & 3 & 4 & 5 \\
\hline $\begin{array}{l}\text { Did the exercise meet your expectations in relation to } \\
\text { networking and sharing experiences? }\end{array}$ & & & 2 & 14 & 12 \\
\hline Was the exercise relevant for you work? & & & 1 & 9 & 18 \\
\hline $\begin{array}{l}\text { Did you feel you had the necessary prerequisites } \\
\text { (knowledge skills etc) to be able to benefit from the } \\
\text { exercise? }\end{array}$ & & 1 & 4 & 14 & 9 \\
\hline Was the level of the exercise satisfactory? & & & 1 & 14 & 11 \\
\hline $\begin{array}{l}\text { The exercise has improved your knowledge of the "con- } \\
\text { tingency planning" concept? }\end{array}$ & & 1 & 2 & 17 & 8 \\
\hline $\begin{array}{l}\text { How did you find this table top exercise as a tool to } \\
\text { enhance your skills on handling of fish diseases? }\end{array}$ & & & 1 & 19 & 7 \\
\hline $\begin{array}{l}\text { How did you find the information you received before the } \\
\text { exercise? }\end{array}$ & & 1 & 5 & 15 & 7 \\
\hline How did you find the hotel and the conference facilities? & & 1 & 9 & 11 & 7 \\
\hline Over all, how did you find the exercise? & & & & 12 & 16 \\
\hline
\end{tabular}




\section{Complementary comments}

The participants were on the evaluation form invited to provide comments within the framework of the following text:

- Comments (in particular on points, where your answer was negative).

- What was the best part of the seminar?

- What could be improved?

The handwritten comments given by the participants ( a total of 23) covering aspects such as information provided before the exercise, the animal health and disease control aspects of the exercise, the management of the exercise, accommodation and food were found very valuable and the comments re-in-forced the views expressed in the table above.

In addition to completing the question and give handwritten comments the participants were also invited at the end of the exercise at working group level to express their views within the context of: Positive observations; suggestions for improvements and recommendations. A summary is given below:

\section{Positive observations}

- The exercise was well constructed with different realistic situations and play-cards.

- Relevant dilemmas caused good discussion without a preconceived opinion on the outcome.

- Good preparation from the organizer, good support during the exercise and very good arrangements for the participants to obtain supplementary information.

- Good colleagues - old and new.

\section{Suggestions for improvements}

- More clear instructions on the role of the directing staff and the role of the group leader.

- The last information document was distributed too late.

- Separate rooms with projectors, and if possible electronic distribution of play-cards and maps.

- More emphasis should be made on compliance with EU-regulations, as the regulations are common for all participating countries. 


\section{Recommendations}

An exercise should be conducted every third year with preparations carried out in each of the participating countries.

The exercise should be conducted during the summertime. 



\section{Acknowledgement}

The Members of the Nordic-Baltic Veterinary Contingency Group would like to express their thanks to the Nordic Council of Ministers for the political support and the financial support made available for the preparation, implementation and valuation of the Viral Hemorrhagic Septicemia (VHS) simulation exercise.

The support made it possible for the national experts from the Nordic and Baltic countries to meet and work closely together during a simulation exercise where the participants were exposed to different disease situations and requested to suggest appropriate disease preventive and control measures.

A special thank shall be addressed to all the organising committee and co-workers in Norway, who made the simulation exercise a great success.

\section{Organization chart}

The activities of the Nordic-Baltic Veterinary Contingency Group are carried out within the framework of allocations given to Nordic working group for microbiology and animal health/animal welfare.

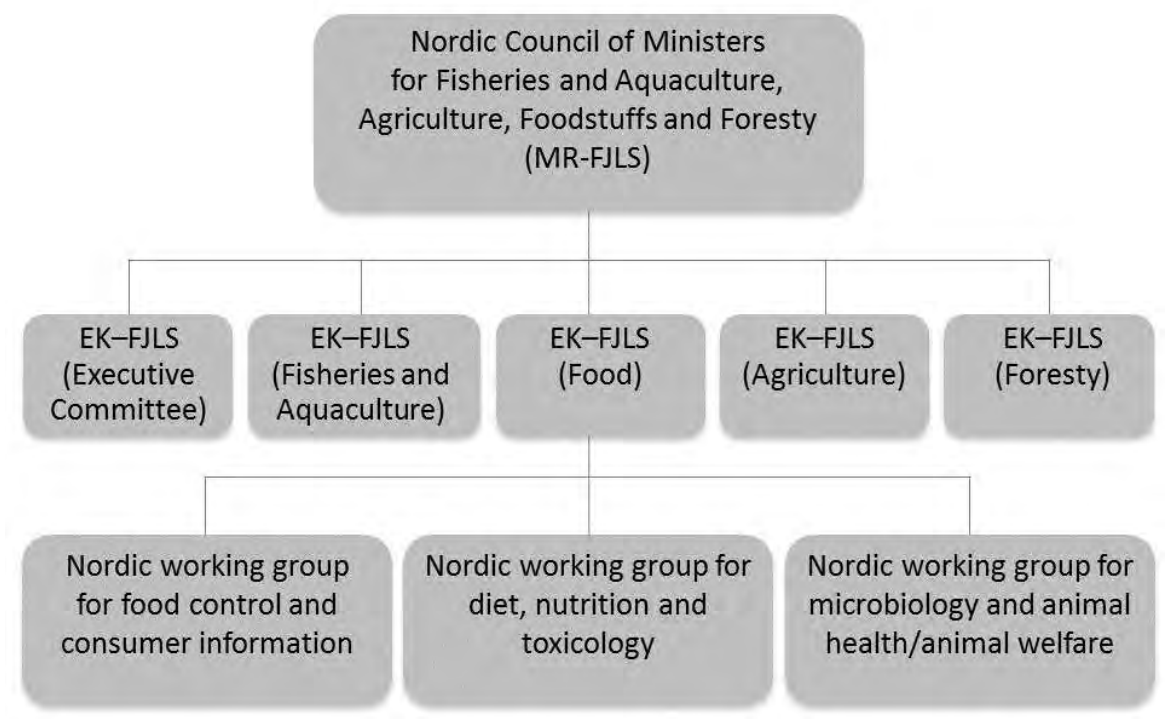





\section{Literature}

Council Directive 2006/88/EC of 24 October 2006 on animal health requirements for aquaculture animals and products thereof, and on the prevention and control of certain diseases in aquatic animals.

Commission Regulation (EC) No 1251/2008 of 12 December 2008 implementing Council Directive 2006/88/EC as regards conditions and certification requirements for the placing on the market and the import into the Community of aquaculture animals and products thereof and laying down a list of vector species.

Commission Decision 2009/177/EC implementing Council Directive 2006/88/EC as regards surveillance and eradication programmes and disease-free status of Member States, zones and compartments http://ec.europa.eu/food/animal/ liveanimals/aquaculture/heath_status_en.htm

OIE Aquatic Animal Health Code, http://www.oie.int/en/international-standardsetting/aquatic-code/access-online/ 



\section{Sammendrag}

Denne rapporten inneholder informasjon om Øvelse TROUT 2013, en nordisk-baltisk Table-top simuleringsøvelse hvor Viral hemorrhagisk septikemi (VHS) hos oppdrettsørret var tema. Øvelsen var laget av medarbeidere i Mattilsynet og ble gjennomført i Bergen i desember 2013. Gjennom det forberedende arbeidet og planleggingen av øvelsen la Nordisk Baltisk Veterinær Beredskapsgruppe (NBVCG) vekt på at mange oppdrettsanlegg og fiskedammer har hatt store produksjonstap som følge av utbrudd av smittsomme fiskesykdommer. En av de mest tapsbringende virussykdommene er Viral hemorrhagisk septikemi (VHS).

Målet for øvelsen var å teste nasjonale beredskapsplaner mot VHS. Øvelsen var basert på realistiske, men oppdiktede mistanker og utbrudd i eksisterende oppdrettsanlegg og lokaliteter i Norge. Scenariet ble utarbeidet av eksperter på fiskehelse fra Norge.

Deltakerne på øvelsen - alle ansatte hos veterinærmyndigheter og ved diagnostiske laboratorier - ble gjennom øvelse delt i arbeidsgrupper, hvor målet var å diskutere utfordringer relatert til sykdomsovervåking, forebygging og utrydding. Fokuset var på å trene på og bli kjent med de bestemmelser og tiltak som er gitt i rådsdirektiv 2006/88 / EC og nasjonale beredskapsplaner. Deltakerne kom fra 9 land - Danmark, Estland, Færøyene. Finland, Island, Latvia, Litauen, Norge, Sverige og Åland.

Øvelse TROUT 2013 ble funnet å være et svært verdifullt verktøy for testing av nasjonale beredskapsplaner mot VHS, og øvelsen var en suksess. Den korte teoridelen som ble gjennomført før øvelsen ga deltakerne en mulighet til å bli oppdatert på virologi, diagnostiske metoder, epidemiologi og distribusjon av VHS og på overvåking og kontrolltiltak som er skissert i EUs lovgivning og OIE's Aquatic Animal Health Code. De ulike elementene i Øvelse TROUT 2013 hjalp deltakerne til å få en bedre forståelse av kriseberedskap. Scenariet, med en utvikling i sykdomssituasjonen i løpet av øvelsen, utfordret deltakerne til risikovurderinger og beslutningsprosesser som kan oppstå under virkelige VHS utbrudd. 



\title{
Annexes
}

\author{
Annex 1. Programme
}

\section{Programme for presentations and the simulation exercise}

\begin{tabular}{|c|c|}
\hline $09.00-11.30$ & Introduction \\
\hline $09.00-09.15$ & $\begin{array}{l}\text { Welcome and presentation of participant, speakers: Audur Arnthorsdottir, Iceland and } \\
\text { Siri Løtvedt, Norway }\end{array}$ \\
\hline $09.15-10.15$ & About VHS: distribution, virus and clinic. Speaker: Niels Jørgen Olesen, Denmark \\
\hline $10.30-11.00$ & Relevant EU and OIE regulations/guidelines. Speaker: Aud Skrudland, Norway \\
\hline $11.00-11.30$ & Practical information and questions by Siri Løtvedt, Norway \\
\hline $11.30-12.30$ & Lunch \\
\hline $12.30-15.30$ & Exercise part 1 Facilitators: Ivar Hellesnes and Aud Skrudland, Norway \\
\hline $15.30-17.00$ & Presentations from the groups and discussion. Moderator: Siri Løtvedt \\
\hline $17.15-17.45$ & Meeting for staff \\
\hline $18.00-19.30$ & Guided walk through downtown Bergen and Bryggen \\
\hline 20.00 & Dinner \\
\hline
\end{tabular}

Thursday December 5th, Day 2

\begin{tabular}{|c|c|}
\hline $08.30-08.45$ & Motivation for the day, Facilitators: Siri Løtvedt and Aud Skrudland \\
\hline $08.45-12.00$ & Exercise part 2: Group discussions of scenario. Moderators; Ivar and Aud \\
\hline $12.00-13.00$ & Lunch \\
\hline $13.00-14.15$ & Presentation and discussion \\
\hline $14.15-14.30$ & Pause \\
\hline $14.30-15.00$ & Presentation and discussion \\
\hline $15.00-16.00$ & $\begin{array}{l}\text { Evaluation of the exercise. Moderators: Siri Løtvedt and Jørgen Westergaard } \\
\text { Discussions in groups on the value of this exercise } \\
\text { Participants to provide information on } 3 \text { positive experiences and on } 3 \text { points on how to } \\
\text { make it better } \\
\text { Evaluation form to be completed b participants }\end{array}$ \\
\hline 16.00 & The end \\
\hline
\end{tabular}




\section{Annex 2. Organising Committee}

The framework for the simulation exercise TROUT 2013 was created by the Nordic-Baltic Veterinary Contingency Group.

The Members of the organizing committee responsible for the preparation and implementation of the exercise were:

- Siri Løtvedt, Senior Adviser, NFSA, Norway.

- Audur Lilja Arnthorsdottir, MAST, Iceland.

- Aud Skrudland, Adviser, NFSA, Norway.

- Geir Jakobsen, Deputy Director, NFSA, Norway.

- Ivar Hellesness, Senior Adviser, NFSA, Norway.

- Renate Johansen, NVI, Norway. 


\section{Annex 3. Participants}

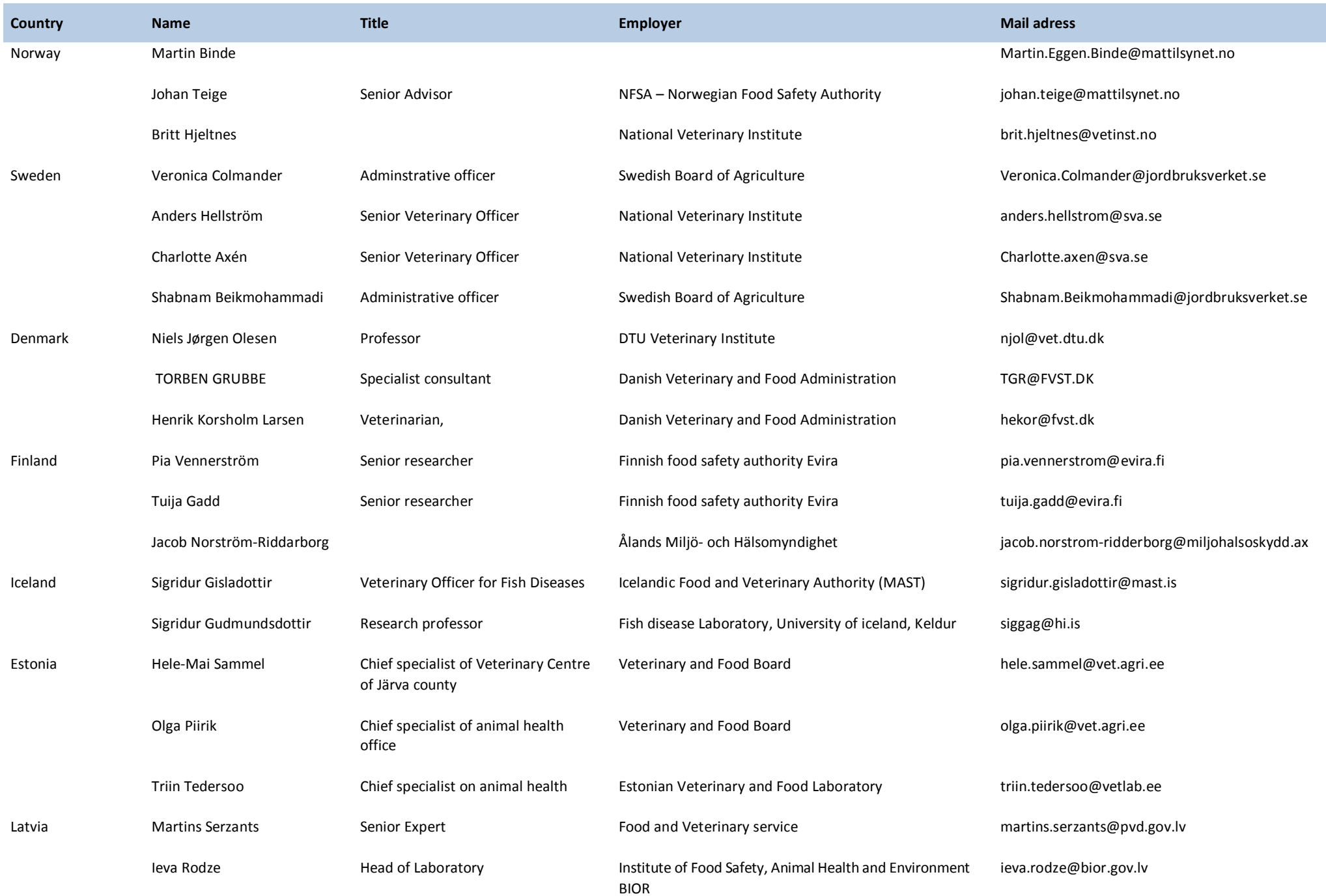




\begin{tabular}{|c|c|c|c|c|}
\hline Country & Name & Title & Employer & Mail adress \\
\hline \multirow[t]{3}{*}{ Lithuania } & Marius Masiulis & $\mathrm{Dr}$ & State Food and Veterinary Service & mmasiulis@vet.lt \\
\hline & Mantas Staskevicius & & State Food and Veterinary Service & mstaskevicius@vet.lt \\
\hline & Orinta Rimasaite & & National Food and Veterinary Risk Assessment Institute & orimasaite@vet.It \\
\hline \multirow[t]{3}{*}{ Faroe Islands } & Birna Mørkøre & Chief Veterinary Officer & Faroese Food and Veterinary Authority & birnam@hfs.fo \\
\hline & Debes H. Christiansen & Head of Diagnostic Laboratory & Faroese Food and Veterinary Authority & debesc@hfs.fo \\
\hline & Ingibjørg Egholm & Veterinary Officer & Faroese Food and Veterinary Authority & ingibjorge@hfs.fo \\
\hline \multicolumn{5}{|c|}{$\begin{array}{l}\text { Facilitators and } \\
\text { Observers }\end{array}$} \\
\hline \multirow[t]{5}{*}{ Norway } & Aud Skrudland & Special Advicer & NFSA & auskr@mattilsynet.no \\
\hline & Ivar Hellesnes & Senior advicer veterinarian & NFSA & ivhel@mattilsynet.no \\
\hline & Geir Jakobsen & Underdirektør & NFSA & gejak@mattilsynet.no \\
\hline & Renate Johansen & & National Veterinary Institute & renate.johansen@vetinst.no \\
\hline & Hedda Højland Aas & National Contingency Coordinator & NFSA & \\
\hline \multicolumn{5}{|l|}{ NBVCG } \\
\hline Denmark & Hanne Hansen & Veterinarian, Specialist consultant & Danish Veterinary and Food administration & hmh@fvst.dk \\
\hline Iceland & Audur Lilja Arnthorsdottir & Veterinary epidemiologist & MAST & audur.arnthorsdottir@mast.is \\
\hline Estonia & Maarja Kristian & $\begin{array}{l}\text { Head of animal health, welfare and } \\
\text { feedingstuffs department }\end{array}$ & Veterinary and Food Board & maarja.kristian@vet.agri.ee \\
\hline Norway & Siri Løtvedt & Senior Adviser & NFSA & simlo@mattilsynet.no \\
\hline Finland & Sirpa Kiviruusu & Senior veterinary officer & Finnish food safety authority Evira & sirpa.kiviruusu@evira.fi \\
\hline Latvia & Madara Stinka & $\begin{array}{l}\text { Head of the animal disease survei- } \\
\text { lance unit }\end{array}$ & Food and Veterinary service & Madara.Stinka@pvd.gov.lv \\
\hline Sweden & Elisabet Lindal & Veterinary Inspector & Swedish Board of Agriculture & elisabet.lindal@jordbruksverket.se \\
\hline NBVCG & Jørgen Westergaard & Veterinarian Ph.D & ADC-Consult & adc-consult@youmail.dk \\
\hline
\end{tabular}




\section{Annex 4. Information on rainbow trout farming and VHS in participating countries}

The organizing committees invited prior to the conduct of the simulation exercise all participating countries to provide information on the following 4 main topics:

- Topic 1: Aquaculture production of rain brown trout (Oncorhynchus mykiss).

- Topic 2: The presence of wild stocks of rainbow trout or trout (Salmon trutta).

- Topic 3: The implementation of the provisions of Council Directive 2006/88/EC in national legislation.

- Topic 4: The health status with regard to VHS.

Topic 1: Aquaculture production of rainbow trout (Oncorhynchus mykiss)

\section{Sweden}

Rainbow trout is one of the most common species that are farmed in Sweden (about 90\% in 2011). During 2011 Sweden produced approximately 10,000 tons rainbow trout in fresh weight.

\section{Estonia}

Estonian aquaculture is characterised by high fragmentation into many small-scale enter-prises, different products and different production methods.

Some farms are simultaneously engaged in several areas, such as commercial fish farming, angling tourism and farming of fish for restocking purposes. Commercial fish farming comprises the most important part economically and is dominated by large red-flesh rainbow trout production. There are numerous owners of small ponds who farm fish for fun or to obtain additional income and develop angling tourism. Also, juvenile fish are farmed for the purpose of restocking natural bodies of water. 


\section{Iceland}

The first import of rainbow trout eggs was in 1951 from Denmark. There was no import of rainbow trout until the year 2007 when 5 litres of triploid rainbow trout eggs were imported from Denmark. There have been imports every year since and the parent fish are subject to wide disease screening in Denmark. In 2012 a total of 260 litres of eggs were imported on eight occasions by three companies. The same year the total production of rainbow trout was 422 tonnes.

\section{Norway}

The anuual production in 2012 was 70,000 tons of rainbow trout.

\section{Types of farms or ponds, size and numbers}

\section{Sweden}

Most of the rainbow trout are farmed in freshwater in the continental zone, both at land based farms and at farms with sea cages. It's common that the fingerlings are held at a land based farm the first year and are later moved to cages where they are held until slaughter. There are about 130 farms in Sweden that keep rainbow trout.

\section{Finland}

Altogether 331 fish farming enterprises were in operation in 2011. Of these, 178 farms operated in intensive food fish production and 103 farms concentrated on intensive fry production, with some farms representing both production lines. A total of 208 farmers operated extensive natural food ponds. However, natural food ponds rarely produce rainbow trout, but other salmonid species (e.g. whitefish (Coregonus ssp.)) for stocking purposes.

\section{Estonia}

In 2012 there were 28 approved fish farms in Estonia. 19 rainbow trout farms (by location), two carp farms, two eel farms, one sturgeon farm, one whitefish farm, one small African catfish farm, two state-financed farms for the cultivation of salmonids for restocking operated in Estonia in 2012.

There were 2 fish farms with production more than 100 tonnes fish per year, 16 farms with production 5-100 tonnes fish per year, and 10 with production less than 5 tonnes fish/year. 
Aquatic organisms were produced in ponds, raceways and recirculation systems. Net pens were used only in fresh water, in a power plant effluent water channel.

There are over 60 fishing tourism enterprises and small-scale fish farmers in Estonia that buy fish from approved fish farms and offer angling services in their ponds. These enterprises fall into two categories: those that focus on quick servicing of passing tourists; and those that offer fishing opportunities alongside other farm tourism services. The number of fish farms changes rapidly, even within a single year, as some farms go out of business, while others begin construction activities but have yet to sell their production.

\section{Iceland}

Farm 1: Hatchery. Annual capacity ca. 300,000 juveniles (50-80 gr.) sold to ongrowing farms, as well as put and take fishing lakes. The farm consists of 3 separate epidemiological units, one of which consists of four earth ponds (the only earth pond farm in Iceland). Annual production/biomass ca 10 tn. (Southwest Iceland).

Farm 2: Hatchery. Water mass capacity ca $750 \mathrm{~m}^{3}$, producing around $500,000-1,000,000$ juveniles for sea based ongrowing farms (supplying their own juveniles, see "Farm 3").(West Iceland).

Farm 3: On-growing sea cage farm consisting of three sites where two are in the same fjord and considered the same epidemiological unit. Annual allowed maximum biomass is 2;200 tonnes, but the total production in 2012 was $366 \mathrm{tn}$. (West Iceland).

Farm 4: Hatchery and ongrowing, arctic char and rainbow trout: Land based farm with one sea cage. The land based farm has both outdoor and indoor tanks. Annual capacity: Around 90 tns. The farm is a small scale one, with a small proportion of rainbow trout. (West Iceland)

Farm 5: Hatchery and ongrowing land based farm. The farm has multiple species; Wild Atlantic salmon, rainbow trout and arctic char (Salvelinus alpinus). Annual estimated production of rainbow trout is 25 tonnes and arctic char 15 tonnes. (Northeast Iceland).

Farm 6: Very small land based on-growing production of rainbow trout with connection to a put and take fishing pond. The company is currently under restrictions due to a BKD outbreak. (Northeast Iceland)

Farm 7: On-growing sea cage farming of rainbow trout. Annual production has been estimated to become 60 tonnes in 2013. (Southeast Iceland). 


\section{Latvia}

In Latvia are authorised about 25 trout farms, including angling pounds. Production amount approximately is 45 tons per year. Type, mainly are recirculation basins.

\section{Norway}

The vast majority of the production is in saltwater based, farms with floating cages. There are a few aeras in the inland with freshwater farms producing in ponds or tanks.

\section{Denmark}

In Denmark, there are registered 251 aquaculture production businesses (APB's) with salmonids. The majority of these are freshwater fish farms, but 20 of the 251 APB's are marine fish farms with production in net cages and 9 APB's are saltwater tanks/raceways production.

The marine fish farms produce rainbow trout. Rainbow trout of $800-$ $1,200 \mathrm{~g}$. are introduced from freshwater fish farms into the marine farms in April/May, and are slaughtered in October/November/December at a size of 3-5 kg. The marine fish farms also produce of rainbow trout roe for the international market.

Farming of rainbow trout in freshwater constitute the traditional Danish aquaculture industry. Although, rainbow trout constitutes approximately $99 \%$ of the production of salmonids in Danish fish farms, brown trout (Salmo trutta) and brook trout (Salvelinus fontinalis) are also produced in some freshwater fish farms.

The majority (169 out of 223) of the freshwater APB's are registered with the farm production "Grow out for human consumption". The production in these farms is aimed at producing fish for consumption or export of live fish to the European market. The fish for these purposes typically have a size of 200-500 g., which is usually achieved between 11 and 18 months.

Twenty three of the APB's with salmonids are registered with the farm production "Brood stock". In Danish brood stock farms there is a significant production of eyed ova in particular of rainbow trout. Eyed ova are used both as a basis for the Danish aquaculture production of rainbow trout and for export to many countries in Europe, Africa, Asia and Latin America. In addition, 13 APB's are registered as hatchery or nursery.

Finally, 18 ABP's produce fry or smolt for stock enhancement of wild stocks of salmon and trout. 


\section{Lithuania}

In Lithuania are 20 farms authorized, from which 2 are with ponds. The maximum capacity could be of 46.7 tones per year.

\section{Geographical areas}

\section{Sweden}

Rainbow trout are farmed in the whole country, from the south to the far north.

\section{Finland}

Fish farms are widely distributed in Finland with some concentrations of farms in the south-western part.

\section{Estonia}

The territory of the whole country.

There are biggest rainbow-trout production farms in the next counties: Lääne-Virumaa, Jõgevamaa and Saaremaa.

A map of Estonian fish farms has been prepared and it shows the categorisation of farms according to the disease situation (VHS, IHN; $\mathrm{KHV}$ ) and to the production of the different fish species.

\section{Iceland}

Farms are spread around the country, though most of them are located in the west and north-east. One farm is located in south-east Iceland, one in the south-west (in Reykjavik).

\section{Latvia}

Whole territory of country.

\section{Norway}

Along the coast and an area in Valdres in the County of Oppland.

\section{Denmark}

The Danish freshwater APB's is almost entirely based in Jutland. A few ABP's with the purpose of restoration of wild stock are located on Funen, Zealand and Bornholm.

The marine fish farms are located in the Belt Sea, south and west of Zealand, along the eastern coast of Jutland and one near the island Samsø. All ABP's are located in relatively wind protected areas. 


\section{Lithuania}

Whole territory, but the main farms are located in eastern part.

\section{Providing of eggs and alevins}

\section{Sweden}

Sweden has a few farms that provide other farms with eggs. Sweden does also import eggs, mostly from Finland and Denmark.

\section{Finland}

There are fish farms maintaining a broodstock for breeding purposes and where eggs and fry are produced in a controlled environment.

Both natural food ponds and fish farms produce fingerlings. There are 103 fish farms concentrated on fry production and total of 208 farmers operated natural food ponds in Finland. The fry reared on fish farms is fed exclusively on industrial feed and is mainly supplied for further rearing as food fish. Fish reared in natural food ponds go mainly for stocking.

The production has developed so that the flow of live fish is from inland to the sea. The fry for both stocking and production of food fish are reared in inland waters. However, more than $80 \%$ of the final growth of food fish takes place on marine area or offshore.

\section{Estonia}

The source of the rainbow trout eggs is mostly the Denmark and Finland VHS-free disease areas, and fish farmers growing juvenile fish in the hatcheries. Also some farmers grow out and sell juveniles to the other farmers in the country. Some farms have their own broad stock and eggs, for example, salmon farm growing fish for restocking purposes (wild to wild -Põlula fish farm).

\section{Iceland}

All eggs come from two suppliers in Denmark, Aqua Search Ova ApS and Troutex ApS. Alevins are produced in four farms. Most of the juveniles produced are used for the farms own production, although there are farms that produce for other companies with ongrowing farms.

\section{Norway}

Eyed eggs are supplied from 2 producers, one of these has a breeding program. There is some transfer of eyed eggs from Denmark.

Smolt is produced in freshwater based farms along the coast. They have no contact with farms for the ongrowing fish. 


\section{Lithuania}

All alevins are imported.

\section{Harvesting and processing}

\section{Sweden}

Most farms have a processing establishment at the farm or just a few miles from the farm. There are no larger processing establishments that receives fish from several farms which is more common in Norway.

\section{Finland}

Harvest of fish is done by the fish farmers. Some of the farmers may have fish processing facilities themselves, but there are several processing plants buying harvested fish from farmers directly. The list of activities and the number of establishments carrying out fish processing is found in: http://www.evira.fi/portal/en/food/manufacture_and_sales/food_ establishments/approved+establishments/ (Approved establishments handling fishery products)

\section{Estonia}

Commercial fish farmers sell a variety of products: live fish as restocking material or for "put-and-take" ponds, as well as gutted and processed fish. The official statistics of fish farming production from 2000-2011 are presented in Table 1.

A clear trend towards increasing red-flesh rainbow trout production was evident until 2010. However, the heat wave in 2010 caused a loss in production, and rainbow trout production volumes have not since recovered. The red-flesh rainbow trout is marketed in Estonia.

Table 1. Estonian fish farming production ( $t$ ), 2000-2011

\begin{tabular}{lcccccccccccc} 
Year & 2000 & 2001 & 2002 & 2003 & 2004 & 2005 & 2006 & 2007 & 2008 & 2009 & 2010 & 2011 \\
R. trout & 313 & 412 & 287 & 304 & 394 & 451 & 520 & 622 & 649 & 790 & 584 & 622 \\
\hline
\end{tabular}

Source: Statistics Estonia

\section{Iceland}

All the on-growing farms perform their own harvesting and processing for the market.

Latvia

No specialized fish processing plans. 


\section{Norway}

On the coast there are large harvesting plant where the fish are transported in Well boats. In the inland there are mostly harvesting and processing plants close to the productions site. The processing plants have approval based om national regulations on fish health and welfare and hygiene regulations(852-853/2004)

Fish produced in Sweden and Denmark may be processed in some of the larger processing plants in the inland of Norway

\section{Denmark}

In 2011, the total aquaculture production of salmonids in Denmark was 38,055 tons. The production of rainbow trout was 37,531 tons and thereby constitutes $99 \%$ of the Danish aquaculture production of salmonids.

The 20 marine APB's produced 10,854 tons of rainbow trout and 323 tons of roe.

The freshwater APB's produced the remaining 26,590 tons of rainbow trout of which approximately $50 \%$ is slaughtered for consumption, $20 \%$ is exported alive, $15 \%$ is moved to other freshwater APB's, $10 \%$ is moved to marine APB's and $5 \%$ is moved to put $\&$ take ponds.

In 2011, the salmonid APB's produced was 337 million eyed ova. The production of rainbow trout eyed ova was 324 million eyed ova and, thereby, constitutes more than $95 \%$ of the Danish aquaculture production of salmonid eyed ovas. Approximately $75 \%$ of the eyed ovas is exported.

\section{Lithuania}

No specialised fish processing plants.

\section{Health controls}

\section{Sweden}

The Swedish board of Agriculture is the competent authority and is therefore responsible for health control at fish farms. In Sweden we have an organization called Fiskhälsan $\mathrm{AB}$ (Fish health service) that conducts the health control in the field. Fiskhälsan has two programs, one that is compulsory for all farms and one that is optional. We finance a large part of the compulsory control and the other part is financed by members fees. All approved fish farms have to be a member in Fiskhälsan $A B$ and all farms with susceptible species for VHS are sampled every year for virus analysis. 


\section{Finland}

Official control in aquaculture farms is carried out in accordance with to Council Directive (2006/88/EC) and Animal Disease Act (55/1980 and amendment 408/2008).

Evira is responsible for the organisation and implementation of animal health controls. The RSAAs are responsible for controls within their regions. Municipal Veterinary Officers are responsible for carrying out animal health controls at holdings. In fish and crayfish farms and in the high risk processing and slaughtering establishments, risk-based animal health surveillance is applied. Official controls consist of regular inspections, visits, audits, and where appropriate, sampling, for each aquaculture production business, taking account of the risk the aquaculture production business. Minimum inspection frequency is once in every four years. Evira has made a guidance book and check lists for inspections to aquaculture farms.

The sale or transfer of fish, crayfish or mussels for food, on-growing or restocking from farms or from ponds with natural nutrition is not permitted without a health authorisation. The health authorisation system collects information about the aquaculture industry and promotes the prevention, control and eradication of diseases in aquaculture animals. According to Fish Council Directive (2006/88/EC) and Animal Disease Act (55/1980, amendment 408/2008) farmers of aquaculture animals have to apply for the health authorisation for their operation from Evira or local authorities in the province of Åland. A list of authorised Finnish businesses and their processing establishments has been published on Evira's web pageshttp://www.evira.fi/portal/en/animals/ animal_health_and_diseases/controlling_animal_diseases

\section{Estonia}

The Veterinary and Food Board (VFB), is a governmental agency responsible for enforcing the requirements of veterinary, animal health and animal welfare,food safety, market regulation and farm animal breeding legislation. It supervises implementation of these requirements and is under the subordination of the Ministry of Agriculture.

The organisation of the Veterinary and Food Board consists of the Central Office and 15 local offices - Veterinary Centres in the counties. When the main objective of the Central Office is to coordinate supervision, the local offices carry out supervision.

The main objective of the diagnostic examinations is the elimination of diseases which has been the goal of systematic activity by the veterinary services for years. The National Infectious Animal Disease Control Programme (NIADC) covers the following aquatic animal diseases: infectious 
salmon anaemia, viral haemorrhagic septicaemia, infectious hematopoietic necrosis of fish, and herpesvirosis of carps.

Individuals who carry out the proceedings foreseen in the programme are authorised veterinarians and, in case of aquatic animal health, they are mostly county specialists in animal health. At the beginning of the year inspections are planned on the risk-based surveillance principle (usually once or twice per year, with or without sampling). Reports of the inspections are completed and send to the animal health office of the Veterinary and Food Board twice per year.

\section{Iceland}

Health controls are according to Directive 2006/88/EC which has been implemented in the national legislation with regulation nr. 1254 from 2008.

\section{Latvia}

Food and Veterinary service supervised authorised aquaculture farms annually. Fish disease surveillance is in place for VHS and IHN. Veterinarians also ensure supervision of aquaculture farms.

\section{Norway}

There is compulsory health control performerd by authorized personal in broodstock farm and smolt producing units every month. In ongrowing plants every 2-3 months.

NFSA performs yearly inspection and sampling for VHS, IHN in all reainbow trout farms.

\section{Denmark}

The aquatic animal health surveillance in Denmark is based on the obligation to notify suspicion of animal diseases, the obligation to notify increased mortality, routine inspections and laboratory examinations of surveillance samples.

The obligation to notify suspicion of animal diseases: The Danish Animal Health Act of 2004 is the legislative basis for the current notification procedure.

The notifiable animal diseases, which are listed in Executive Order No. 54 of 26 January 2011, are divided into two groups: list 1 and list 2. Any suspicion of a disease on list 1 must immediately be notified to the Danish Veterinary and Food Administration (DVFA), whereas notification of a disease on list 2 is only mandatory after confirmation of the disease. The Danish list 1 of notifiable diseases includes the following fish diseases: EHN, EUS, SVC, VHS, IHN, ISA and KHV. The Danish list 2 of notifiable diseases includes the following fish diseases: BKD and IPN. 
According to the Animal Health Act, any farmer is obliged to call a veterinarian right away if he suspects a notifiable disease. The veterinarian must immediately notify the DVFA if he suspects a disease on the list 1.

In addition to the general provisions in the Animal Health Act, the obligation to notify suspicion of certain aquatic animal diseases is further specified in Executive Order No. 968 of 18 July 2013 on surveillance and control of certain diseases of aquatic organisms and in Executive Order No. 967 of 18 July 2013 on surveillance and registration of IPN and BKD.

Executive Order No. 968 of 18 July 2013 concerns the following fish diseases: EHN, VHS, IHN, ISA, KHV and emerging diseases. According to $§$ 5 of Executive Order No. 968 of 18th July 2013:

- A person responsible for aquatic organisms, which are suspected of being infected with one of the diseases, shall call a veterinarian.

- A person responsible for processing establishment shall notify the DVFA if occurrence of one of the diseases is suspected.

- Transporters, employees of laboratories and other professionals shall immediately notify the DVFA if occurrence of one of the diseases is suspected.

Executive Order No. 967 of 18th July 2013 concerns IPN and BKD. According to $\S 12$ of this Executive Order, fish farms with health status as being free or covered by the surveillance program shall immediately notify DVFA if the fish show clinical signs of IPN or BKD.

A veterinary officer from the DVFA will inspect the farm within four hours after a notification of a suspicion of one of the above mentioned fish diseases. If the veterinary officer cannot rule out the suspicion of a list 1 disease, the farm is placed under official surveillance, and test material is collected and dispatch to the National Veterinary Institute at the Technical University of Denmark.

The obligation to notify increased mortality

The legislative basis for the obligation to notify increased mortality is Executive Order No. 965 of 18th July 2013 and Executive Order No. 968 of 18th July 2013.

According to $\S 5$ of Executive Order No. 965 of 18th July 2013, a condition for authorization of an aquaculture farm is record keeping of mortality in each epidemiological unit of the farm. These mortality records shall be kept for at least 5 years and must be presented on the request of DVFA.

According to $\S 6$ of Executive Order No. 968 of 18th July 2013, a person responsible for aquatic organisms shall, if an increased mortality in 
aquatic organisms is registered, immediately call a veterinarian or notify it to DVFA.

A veterinary officer from the DVFA will inspect the farm after a notification of increased mortality. If the veterinary officer cannot rule out the suspicion of a listed disease, the farm is placed under official surveillance, and test material is collected and dispatch to the National Veterinary Institute at the Technical University of Denmark.

Routine inspections: During the routine inspections conducted as part of the official surveillance (read more about the frequencies under "Laboratory examinations of surveillance samples"), all farm facilities (cages, tanks and ponds) are checked for dead, weak fish and fish showing abnormal behaviour. Where possible the newly dead fish (which are not decomposed), weak fish and fish with abnormal behaviour examined for clinical signs or necropsy signs of a contagious fish disease.

The discovery of recent clinical signs that could indicate an outbreak of a contagious fish disease, or if the official veterinarian has other reasons to suspect that fish may be infected, at least a pooled sample of ten fish must be taken and send for laboratory examination at the NVI. The sample should, if possible, consist of the newly dead fish, weak fish and fish with abnormal behaviour. If there isn't a sufficient number of fish with clinical signs, the sample should be supplemented with healthy fish, selected from the cages, tanks or ponds, where the largest number of dead fish or fish with clinical signs of disease.

If freshly dead or weak fish or fish with abnormal behaviour are found, but the clinical signs and autopsy findings do not indicate a contagious fish disease, sampling is not mandatory, but can be taken on the request of the official veterinarian is such tests may be necessary for a differential diagnosis.

If wild fish are suspected to be infected, the official veterinarian ensure that suitable samples are taken and examined by the relevant clinical and laboratory methods, so the suspicion can be either rejected or confirmed, and so it can be estimated if the possible presence of the disease involves a significant risk to aquaculture fish.

Laboratory examinations of surveillance samples: DVFA performs a targeted surveillance for VHS, IHN and SVC. All APBs are inspected at least annually, and samples are taken at least every second years. Brood stock holdings are inspected twice a year, and samples are taken in connection with each inspection. A sample for laboratory examination consists of 30 fish divided into three pools of 10 .

APBs that are registered free of IPN are inspected and a sample of 30 fish is taken for virological examination twice a year from brood stock 
holdings and once a year from production holdings. APBs that are registered free of BKD are inspected and a sample of 30 fish is taken for bacteriological examination twice a year from brood stock holdings and once a year from production holdings.

\section{Lithuania}

State Food and Veterinary service of Lithuania supervised authorised aquaculture farms annually. Fish disease surveillance is in place for VHS and IHN. Authorized or official veterinarians also ensure supervision of aquaculture farms.

\section{Topic 2: Any wild stocks of rainbow trout or trout (Salmo trutta)}

\section{Sweden}

Trout are located throughout the country, from the lowlands to the mountains, and in the coastal area from Haparanda to Stromstad. Rainbow trout are only farmed and released in Sweden. We have no wild populations that haven't been bred at a farm.

\section{Finland}

All natural waters in Finland are habited (or potentially can be habited) with wild rainbow trout and trout.

\section{Estonia}

Only native species may be released in natural bodies of water in Estonia. Fish farmers who produce fish for restocking are required to maintain biodiversity and to not mix genetically different populations. The restocking of farmed juvenile fish into natural bodies of water is regulated by the Programme for Protection and Restocking of Endangered Species Requiring State Protection 2002-2010, which will be updated in 2013. Restocking through fish farming has been financed mainly from the state budget through the Environmental Investment Centre.

There are two fish farms in Estonia exclusively engaged in the production of salmonid stocking material: Põlula Fish Farming Centre (a state enterprise) and OÜ Õngu Noorkalakasvandus.

In 2011salmon introductions into Estonian waters have been successful.

Stocked salmons have returned to the Estonian Rivers and spawned there, which indicates that the salmon populations of these rivers can be restored. In coastal fishing in the Gulf of Finland, stocked salmon have accounted for over $70 \%$ of the total catch in some regions. Sea trout 
introduced by the Õngu Fish Farm in the coastal waters of Hiiumaa accounted for more than 75\% of the catch in Õngu Creek from 1995-2007.

\section{Iceland}

Iceland has no wild stocks of rainbow trout. Iceland has wild stocks of trout (Salmo trutta), both anadromous (migrates between fresh water and the sea) and potamodromous (migrates within freshwater only).

\section{Latvia}

No wild stocks for rainbow trout.

For trout (Salmo trutta) a national restocking programme has been established. Five government fish farms obtain eggs from Baltic Sea trout's and grow to smolt stage.

\section{Norway}

There are not supposed to be wild(or escaped) stocks and rainbow trout in freshwater lakes or in seawater. Salmo trutta are found in fresh and seawater.

\section{Denmark}

Rainbow trout: Through the years, rainbow trout has been widely distributed in the Danish freshwaters and in the sea around Denmark. The latter due to stock enhancement projects and escapees from marine fish farms. In Danish streams, the occurrence of rainbow trout follows the distribution of fish farms, which means that it has been and still is most common in watercourses in Jutland. Although the number of escapes from fish farms have been reduced considerably, there are still so many escapes, that rainbow trout can be found almost anywhere in streams with fish farms. Most of the rainbow trout, found in streams on the islands, originates from escaped rainbow trout originating from marine fish farms and not from the freshwater fish farms in Jutland.

Despite the large number of escaped rainbow trout, fry has only been found in a few occasions. Natural populations of rainbow trout are not known to have emerged, and it is expected that the species would disappear from Denmark if escapes and releases were discontinued.

Trout:The trout are found in almost all Danish streams, and there has within the last decade been registered trout in streams on the islands Als, Bornholm, Falster, Langeland, Lolland, Mors, Møn, Tåsinge and Ærø as well as on Funen, Zealand and in Jutland. It is missing only on the smaller islands, which probably is caused by the lack of appropriate streams. Approximately 360 of the 887 Danish water catchment areas have a selfsustainable wild trout population. Some sports fishery organisations en- 
hance the trout stocks in local watercourses by stripping ascending spawners, hatch the eggs and produce fry or fingerlings under artificial conditions and release those in the watercourse as a compensation of the fish caught during the fishery season. Such projects have to be approved by the authorities in order to ensure a sustainable fish population.

\section{Lithuania}

In Lithuania we do not have any wild stocks of rainbow trout (except in small rivers, were small quantities lives in natural conditions) or trout (Salmo trutta).

\section{Topic 3: How are 2006/88/EC implemented in national regulations?}

\section{Sweden}

The directive was fully implemented in national legislation in 2008.

\section{Finland}

2006/88/EC is implemented in national regulations concerning fish farming. Please see for example point 1.5. above. List of Finnish national regulations implementing 2006/88:

- MMM 1346/1995 listed diseases and disease notification.

- MMM 470/2008 implements 2006/88/EC as national regulations including official health control in fish farms and fish processing establishments and control, confirmation and eradication of listed fish diseases.

- MMM 55/1980, amendment 408/2008 Health authorization and Register of aquaculture production businesses and processing establishments.

- MMM 727/2010 VHS restriction area measures.

- MMM 238/2010 and MMM 533/2011 national regulation of keeping register of animal and aquaculture establishments.

\section{Estonia}

The Ministry of Agriculture (MA) has the main responsibility for legislation and implementation regarding the food and feed chain. In purpose to implement Directive 2006/88 to the national regulations the Ministry of Agriculture is completed several new regulations and amendments to 
the Animal Health Law. There are different regulations regarding the aquatic animal health:

- "Rules for aquatic animal disease control".

- Rules concerning movements and trade of aquatic animals.

- Registration and approval of aquaculture production businesses.

- Killing aquatic animals with disease control purposes.

- Regulation "Establishing a list of infectious animal diseases subject to notification and registration".

- Veterinary requirements for keeping aquatic animals.

\section{Iceland}

Iceland has implemented Directive 2006/88 fully in its national legislation.

\section{Latvia}

Cabinet Regulation Nr. 400 "Health requierments for aquaculture animals, products derived from them and their movement, as well as certain aquaculture animal diseases prevention and control" are implementation of "COUNCIL DIRECTIVE 2006/88/EC on animal health requirements for aquaculture animals and products thereof, and on the prevention and control of certain diseases in aquatic animal" in national legislation.

\section{Norway}

Directive 2007(88 are implemented in national regualtions. On some areas the national regulations have rules that are regarded more detailed and stricter than the directive

\section{Denmark}

The orders by which the Council Directive 2006/88/EC is implemented in Danish legislation are:

- Executive Order No. 965 of 18 July 2013 on authorization and operation of aquaculture farms and placement on the market of aquaculture organisms and products thereof.

- Executive Order No. 968 of 18 July 2013 on surveillance and control of certain infectious diseases in aquatic organisms.

In addition to these, the specific executive order on special measures and compensation in connection with eradication of VHS might also relevant to the NBVCG Exercise TROUT 2013, although the executive order will be repealed by 1st January 2014 . 


\section{Lithuania}

The Directive 2006/88 has been implemented and transferred in to national legislation by the Order of the Director of State Food and Veterinary Service on 24th April 2008 No. B1 246 "Veterinary requirements on animal health requirements for aquaculture animals and products thereof, and on the prevention and control of certain diseases in aquatic animals."

\section{Topic 4: Status regarding VHS}

\section{Sweden}

Sweden has a free status from VHS, both inland and coastal zones.

\section{Finland}

According to Finnish legislation (1346/1995) VHS is listed as easily transmissible diseases everywhere in Finland, excluding the province of Åland. In the Province of Åland VHS is listed as opposed, immediately notifiable disease.

\section{Denmark}

The whole continental area of Denmark is free of VHS. Denmark has successfully eradicated the disease from the Danish freshwater fish farms. The eradication programme which has been co-financed by the European Fisheries Fund started in 2009 and the final sampling for documentation of freedom from VHS was conducted during April-May 2013. A description of the eradication of VHS in Denmark is available on the website of the Danish Veterinary and Food Administration.

All marine fish farms has an undetermined health status (category III), because wild fish carrying marine VHS types are present in Danish marine environment and, therefore, pose a potential risk of contamination.

\section{Policy on presence of the disease}

\section{Sweden}

If an outbreak occurs all fish are stamped-out and the farm is disinfected. A previously infected farm is regarded as a high risk farm and is therefore subject to a higher frequency of inspections. Last outbreak was in 2001 in wild fish and 2002 in farmed fish.

\section{Finland}

According to Finnish legislation (1346/1995) VHS is listed as easily transmissible diseases everywhere in Finland, excluding the province of 
Åland. In the Province of Åland VHS is listed as opposed, immediately notifiable disease.

\section{Estonia}

In case of the presence of the disease competent authority and farmers who is involved will follow the Animal Health Law and the „Rules for aquatic animal disease control“; and requirements from the contingency plan for VHS.

Disease control measures include the implementation of biosecurity measures (including destruction of killed fish), empting from live fish, cleaning of the pools of the fish farms, and disinfection under supervision of the competent authority. After cleaning and disinfection pools must stay empty during 6 weeks at the minimum.

\section{Iceland}

VHS has never been detected in Iceland. The competent authority carries out regular screening and in case of detection, as with other serious animal diseases there is a contingency plan in order.

\section{Latvia}

Sampling for IHS and VHS from authorised fish farms are performed annually.

\section{Norway}

Outbreaks will be stamped out. The last outbreak inNorway was on sea water rainbow trout in 2008 .

\section{Denmark}

VHS is an immediately notifiable disease; suspicion of the presence of VHS should be notified immediately to the DVFA. Fish farms suspected of being infected with VHS are put under official restrictions ( $\$ 7$ of Order No. 968 of 18/7-2013). DVFA can put other sites with aquatic organisms in the aquaculture zone of the suspected fish farm under official restrictions ( $\$ 9$ of Order No. 968 of 18/7-2013). Outbreaks of VHS are stamped out (§§ 13-15 of Order No. 968 of 18/7-2013). A containment area is established around infected fish farms ( $\S 17-19$ of Order No. 968 of 18/7-2013). Procedures are described in the Danish Contingency Plan.

\section{Lithuania}

Sampling for IHS and VHS from authorised fish farms are performed annually. 


\section{Areas infected}

\section{Sweden}

No areas infected

\section{Finland}

The Province of Åland, where VHS eradication program is implemented according to Directive 2006/88/EC

\section{Estonia}

There are no infected areas at the moment

Iceland

None

Latvia

No detected

Norway

None

Denmark

None

Lithuania

The is no registered cases of VHS

\section{Disease free zones territories, zones or compartments}

\section{Sweden}

Sweden is disease free.

\section{Finland}

VHS free are all continental and coastal areas within Finnish territory, except the province of Åland.

\section{Estonia}

There is one officially free VHS/IHN compartment:

Äntu fish farm of the Simuna Ivax aquaculture business operator.

Iceland

Iceland is recognised as approved disease free country with regard of VHS and IHN since 2004. (No. 227/04/COL). 


\section{Norway}

Except for a buffer zone close to the Russian border, Norway is VHS free both continetal and in sea water.

\section{Latvia}

No free zones, compartments or fish farms.

\section{Denmark}

The whole continental area of Denmark is free of VHS.

\section{Lithuania}

No officially disease free zones territories, zones or compartments are established.

\section{Annex 5. Laboratory reports}

The participants of the exercise TROUT 2013 received during the group work a number of laboratory reports - a total of six. The laboratory reports are shown below.

- The reports are attached as PDF: http://norden.divaportal.org/smash/get/diva2:794617/ATTACHMENT03.pdf

\section{Annex 6. Health certificates}

A certificate marked "Exercise" and containing all required information related to a consignment of eggs from Denmark to Norway was completed and used during the exercise. A Model of the Intra trade certificate is shown below.

- Please see Certificate in the Commission regulation no. 350/2011, Bilag II Del A: http://norden.divaportal.org/smash/get/diva2:794617/ATTACHMENT04.pdf 


\section{Annex 7. Biomass information}

During the application of fish disease control measures it is important to have information about the number of fish, size of fish and the biomass in each fish pond or tank.

The organisers of TROUT 2013 had for this purpose prepared biomass tables for distribution to the participants. The tables are shown below. 


\begin{tabular}{|c|c|c|c|c|c|c|c|c|c|c|}
\hline \multicolumn{4}{|l|}{ Biomass } & & \multicolumn{6}{|l|}{ Mortality } \\
\hline Tank/pond & number & size $\mathrm{kg}$ & biomass kg & & week no 44 & week no 45 & week no 46 & total & $\%$ & Biomass Mort (KG) \\
\hline 1 & 17,000 & 0.042 & 714 & & 23 & 52 & 156 & 231 & 1,4 & 9.702 \\
\hline 2 & 18,000 & 0.035 & 630 & & 12 & 46 & 100 & 158 & 0,9 & 5.53 \\
\hline 3 & 16,500 & 0.05 & 825 & & 79 & 119 & 268 & 466 & 2,8 & 23.3 \\
\hline 4 & 26,000 & 0,03 & 780 & & 67 & 123 & 234 & 424 & 1,6 & 12.72 \\
\hline 5 & 19,000 & 0.1 & 1,900 & & 15 & 17 & 20 & 52 & 0,3 & 5.2 \\
\hline 6 & 20,000 & 0.05 & 1,000 & & 19 & 212 & 150 & 381 & 1,9 & 19.05 \\
\hline 7 & 12,000 & 0.1 & 1,200 & & 60 & 78 & 102 & 240 & 2,0 & 24 \\
\hline 8 & 12,000 & 0.11 & 1,320 & & 40 & 60 & 80 & 180 & 1,5 & $\begin{array}{r}19.8 \\
0\end{array}$ \\
\hline a & 8,500 & 0.25 & 2,125 & & 36 & 102 & 350 & 488 & 5,7 & 122 \\
\hline b & 8,500 & 1.2 & 10,200 & & 16 & 19 & 34 & 69 & 0,8 & 82.8 \\
\hline c & 13,000 & 0.6 & 7,800 & & 36 & 77 & 89 & 202 & 1,6 & 121.2 \\
\hline d & 8,000 & 1.4 & 11,200 & & 18 & 30 & 40 & 88 & 1,1 & 123.2 \\
\hline e & 6,000 & 1.5 & 9,000 & & 25 & 19 & 45 & 89 & 1,5 & 133.5 \\
\hline$f$ & 12,000 & 0.3 & 3,600 & & 17 & 87 & 156 & 260 & 2,2 & 78 \\
\hline \multirow[t]{2}{*}{ Total biomass } & 196,500 & & 52,294 & Total mortality & 463 & 1,041 & 1,824 & & & 780.002 \\
\hline & & & & Water temperature degrees $\mathrm{C}$ & 11 & 10 & 9 & & & \\
\hline
\end{tabular}

Hatchery - a total of 50.000 egg yolk avelins.

\begin{tabular}{|c|c|c|c|c|c|c|c|c|c|c|c|}
\hline \multicolumn{5}{|l|}{ Biomass } & & \multicolumn{6}{|l|}{ Mortality } \\
\hline & Tank/pond & number & size kg & biomass kg & & week no 44 & week no 45 & week no 46 & total & $\%$ & biomass mort \\
\hline \multirow[t]{5}{*}{ Indoor production } & 1 & 18,000 & 0.05 & 900 & & 12 & 11 & 17 & 40 & 0.2 & 2 \\
\hline & 2 & 18,000 & 0.05 & 900 & & 17 & 8 & 22 & 47 & 0.3 & 2.35 \\
\hline & 3 & 6,000 & 0.1 & 600 & & 6 & 10 & 12 & 28 & 0.5 & 2.8 \\
\hline & 4 & 6,000 & 0.1 & 600 & & 13 & 8 & 32 & 53 & 0.9 & 5.3 \\
\hline & 5 & 6,000 & 0.1 & 600 & & 8 & 8 & 12 & 28 & 0.5 & 2.8 \\
\hline \multirow[t]{8}{*}{ Ponds } & 6 & 6,000 & 0.2 & 1,200 & & 7 & 9 & 12 & 28 & 0.5 & 5.6 \\
\hline & 7 & 6,000 & 0.2 & 1,200 & & 12 & 8 & 32 & 52 & 0.9 & 10.4 \\
\hline & 8 & 6,000 & 0.2 & 1,200 & & 8 & 9 & 6 & 23 & 0.4 & $\begin{array}{r}4.6 \\
0\end{array}$ \\
\hline & 1 & 10,000 & 1.7 & 17,000 & & 12 & 17 & 15 & 44 & 0.4 & 74.8 \\
\hline & 2 & 10,000 & 1.6 & 16,000 & & 8 & 9 & 12 & 29 & 0.3 & 46.4 \\
\hline & 3 & 8,000 & 1.2 & 9,600 & & 12 & 8 & 5 & 25 & 0.3 & 30 \\
\hline & Total biomass & 100,000 & & 49,800 & Total mortality & 115 & 105 & 177 & & & 187.05 \\
\hline & & & & & Water temperature degrees $\mathrm{C}$ & 11 & 10 & 9 & & & \\
\hline
\end{tabular}


Ved Stranden 18

DK-1061 Copenhagen K

www.norden.org

\section{TROUT 2013 - simulating VHS outbreaks}

Fish diseases are a major concern for aquaculture where fish are commercially reared. In the Nordic-Baltic countries aquaculture is currently taking place in freshwater fish farms and in marine fish farms. A range of viral diseases can cause devastating losses to fish rearing and wild fish stocks. Viral hemorrhagic septicemia (VHS) - also known as "Egtved disease" - is a viral fish disease which affects a large number of freshwater and marine fish. The rainbow trout is very susceptible to the disease.

This report provides information on the preparatory work and the conduct a simulation exercise code-named "TROUT 2013". The aim of the exercise was to test National VHS Contingency Plans.
TemaNord 2014:571

ISBN 978-92-893-3905-6(PRINT) ISBN 978-92-893-3906-3 (PDF) ISBN 978-92-893-3907-0 (EPUB) ISSN 0908-6692

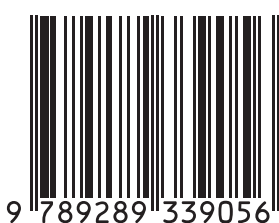

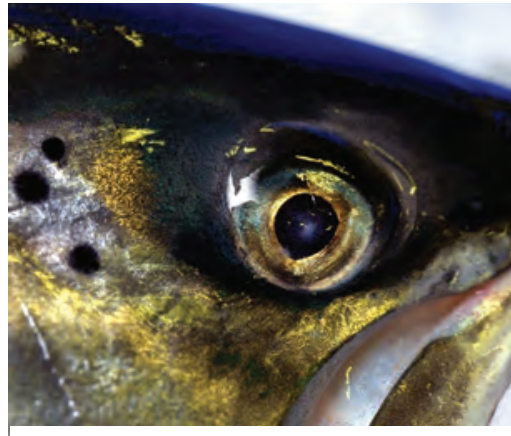

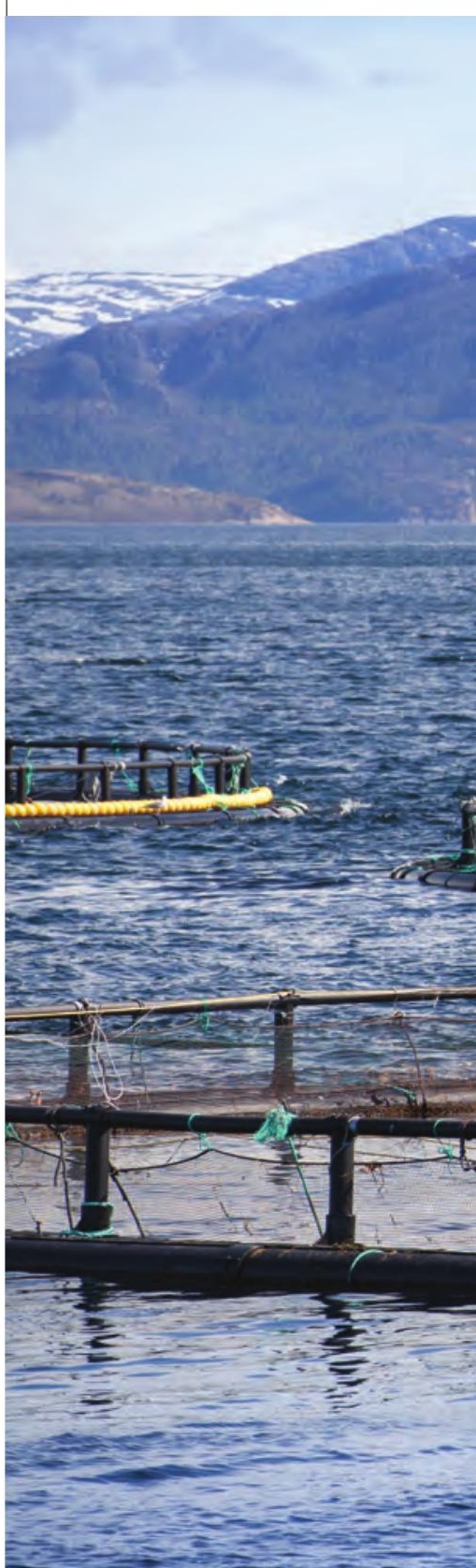

